\author{
Dr. sc. Petra Amižić Jelovčić, izvanredna profesorica \\ Pravni fakultet Sveučilišta u Splitu \\ Drago Kovačević, student \\ Pravni fakultet Sveučilišta u Splitu
}

\title{
HRVATSKI PRAVNI OKVIR SIGURNOSTI I ZAŠTITE MORSKOG OKOLIŠA PRI ODOBALNOM ISTRAŽIVANJU I EKSPLOATACIJI UGLJIKOVODIKA
}

\author{
UDK: 502/504 : $34(497.5)$ \\ Izvorni znanstveni rad \\ Primljeno: 10. 12. 2015.
}

\begin{abstract}
Kako bi se smanjio uvoz energenata i popravila energetska slika Republike Hrvatske, naše su vlasti odlučile oživjeti odobalno istraživanje i eksploataciju ugljikovodika. Preduvjet za to bilo je stvaranje odgovarajućeg pravnog okvira, što se i postiglo donošenjem Zakona o sigurnosti pri odobalnom istraživanju i eksploataciji ugljikovodika u srpnju 2015. godine. Autorica u ovom radu razmatra odredbe navedenog zakona s posebnim osvrtom na zaštitu morskog okoliša. Slijedom toga, analizirane su i odredbe Plana intervencija kod iznenadnih onečišćenja mora u korelaciji s prethodno spomenutim Zakonom.
\end{abstract}

\section{Ključne riječi: pravna regulativa, odobalno istraživanje, odobalna eksploatacija, ugljikovodici, zaštita morskog okoliša, odgovornost za štetu}

\section{UVOD}

Esencijalna pretpostavka gospodarskog rasta i razvoja svake moderne države jest energetska samodostatnost i stabilnost. Energetski sektor u Hrvatskoj jedan je od najvažnijih investitora te posljedično i pokretač ukupnog gospodarstva. S obzirom na nivo ulaganja s ciljem razvoja navedenog sektora, za vjerovati je da će energetika odigrati ključnu ulogu u budućem razvoju Republike Hrvatske. Statistički su podaci iz prethodnih godina ohrabrujući te navode da je ukupni uvoz energije u Hrvatskoj u 2013. godini smanjen za 1,1 \% u odnosu na 2012. godinu, ${ }^{1}$ dok je ukupni izvoz uvećan za $8,7 \%{ }^{2}$

\footnotetext{
1 Prema dostupnim podacima iz Ministarstva gospodarstva Republike Hrvatske, ukupna potrošnja energije u Hrvatskoj u 2013. godini povećana je za 4,1 \% u odnosu na prethodnu godinu. Smanjen je uvoz električne energije, derivata nafte i prirodnog plina, a povećan je uvoz ogrjevnog drva i biomase, ugljena i koksa i sirove nafte. www.mingo. $h r$

2 Pri tome je smanjen izvoz derivata nafte za 1,2\%, dok je izvoz ostalih oblika energije povećan. Ono što treba posebno istaknuti jest vlastita opskrbljenost energijom koja je u 2013. godini iznosila 54,3 \%, što je za 12,4 \% više u odnosu na prethodnu godinu. „Energija u Hrvatskoj 2013“, Godišnji energetski pregled, str. 47, www.mingo.hr
} 
Prednosti nafte i plina, kao neobnovljivih energenata, odavno su poznate, baš kao i činjenica da Jadran njima obiluje. Tako su se na Jadranu prve bušotine pojavile još davne 1961. godine ${ }^{3}$ da bi do 2004. godine 4 bila izrađena 51 bušotina. $\mathrm{Na} 10$ bušotina registrirane su pojave plina, na 5 pojave nafte, 4 imaju status plinske bušotine dok su 32 bušotine bile negativne. Na području epikontinentalnog pojasa Republike Hrvatske nalaze se 3 eksploatacijska polja ugljikovodika ${ }^{5}$ na kojima se već dugi niz godina obavlja eksploatacija prirodnog plina i njegov prijevoz do obale. ${ }^{6}$ Kako eksploatacija ugljikovodika obuhvaća pridobivanje ugljikovodika iz ležišta i oplemenjivanje ugljikovodika, transport ugljikovodika cjevovodima, kada je u tehnološkoj svezi s odobrenim eksploatacijskim poljima, skladištenje ugljikovodika i trajno zbrinjavanje plinova u geološkim strukturama, rizik od velikih nesreća i šteta za ljude i okoliš prisutan je na svakom koraku. Podatak da se, do sada, na Jadranu nije dogodila nijedna velika nesreća prouzročena provedbom odobalnih radova, koji uključuju istraživanje ${ }^{7}$ i eksploataciju ${ }^{8}$ uglikovodika, poslužio je kao potvrda sigurnosti te kao dodatni motiv da se i u budućnosti nastavi s istraživanjem i eksploatacijom ugljikovodika u našem podmorju. ${ }^{9}$

Nakon više godina potpunog zastoja, pokrenuto je istraživanje i stvoreni su uvjeti za velika ulaganja u istraživanje i eksploataciju ugljikovodika. To je osigurano prethodnim stvaranjem zakonskog okvira kojim su zaštićeni nacionalni interesi u energetskom sektoru. Upravo se donošenje Zakona o sigurnosti pri odobalnom istraživanju i eksploataciji ugljikovodika u srpnju 2015. godine smatra onom odlučujućom prekretnicom u području istraživanja i eksploatacije

3 Bušotina Vis -1 .

4 Bušotina Karla - 1.

5 Ugljikovodici znače naftu, prirodni plin i plinski kondenzat, pridobiven u istražnom prostoru i/ili na eksploatacijskom polju u okviru dozvole i ugovora (čl. 4, t. 32. Zakona o istraživanju i eksploataciji ugljikovodika, N. N., br. 94/13, 14/14).

6 Radi se o ekploatacijskom polju Izabela, Sjeverni Jadran i Marica. Prema Zakonu o istraživanju i eksploataciji ugljikovodika, eksploatacijsko polje ugljikovodika znači spojnicama koordinata vršnih točaka omeđen dio prostora na kopnu i/ili moru i dubinski ograničen sukladno utvrđenim granicama ležišta ugljikovodika i lokacijskim uvjetima iz izvršne lokacijske dozvole ishođene od tijela nadležnog za prostorno uređenje (čl. 4, t. 5).

U skladu sa čl. 4, t. 10. Zakona o istraživanju i eksploataciji ugljikovodika, istraživanje ugljikovodika znači sve istražne i ocjenske radove i djelatnosti koji su definirani kao takvi u odobrenom programu rada, kojima je svrha utvrditi postojanje, položaj i oblik ležišta ugljikovodika, njihovu količinu i kakvoću te uvjete eksploatacije, radove i ispitivanja kojima je svrha utvrditi mogućnost skladištenja ugljikovodika i trajnog zbrinjavanja plinova u geološkim strukturama te uvjete eksploatacije, uključujući, ali ne isključivo: a) geofizička i druga geološka snimanja, interpretaciju tako prikupljenih podataka $i$ njihovu studijsku obradu; b) bušenje, produbljivanje, skretanje, opremanje, ispitivanje, privremeno napuštanje ili likvidaciju istražnih bušotina; c) kupnju ili nabavu onih roba, usluga, materijala i opreme koji su potrebni za gore spomenute radove. Istraživanje ugljikovodika dozvoljeno je samo unutar odobrenog istražnog prostora.

8 Eksploatacija ugljikovodika dozvoljena je samo unutar utvrđenog eksploatacijskog polja ugljikovodika i u granicama provjerenog rudarskog projekta (čl. 4, t. 4. Zakona o istraživanju i eksploataciji ugljikovodika).

9 Velike nesreće vezane za odobalne radove mogu imati razorne i nepovratne posljedice za morski okoliš te značajne negativne učinke na priobalna gospodarstva. Vidi: Konačni prijedlog Zakona o sigurnosti pri odobalnom istraživanju i eksploataciji ugljikovodika s konačnim prijedlogom Zakona, Vlada RH, lipanj 2015., str. 2, www.vlada.gov.hr 
Dr. sc. Petra Amižić Jelovčić i Drago Kovačević: Hrvatski pravni okvir sigurnosti i zaštite morskog ... Zbornik radova Pravnog fakulteta u Splitu, god. 53, 2/2016., str. 469.-496.

nafte i plina kojom će se, zasigurno, potaknuti aktivnosti koje će našu državu transformirati iz uvoznika u izvoznika energenata.

\section{PRAVNI OKVIR}

Važeći pravni okvir, kojim se uređuje istraživanje i eksploatacija ugljikovodika u Republici Hrvatskoj, obuhvaća niz zakonskih i podzakonskih propisa. U prvom redu treba istaknuti Zakon o rudarstvu ${ }^{10}$ i Zakon o istraživanju i eksploataciji ugljikovodika ${ }^{11}$ te Zakon o sigurnosti pri odobalnom istraživanju i eksploataciji ugljikovodika koji će predstavljati okosnicu ovog rada. Također, od izuzetne su važnosti za ovu problematiku Pomorski zakonik Republike Hrvatske, ${ }^{12}$ Zakon o zaštiti okoliša ${ }^{13}$ i Zakon o osnivanju Agencije za ugljikovodike. ${ }^{14}$ Od podzakonskih propisa najbitniji su, svakako, Pravilnik o bitnim tehničkim zahtjevima, sigurnosti

10 Zakon o rudarstvu (N. N., br. 56/13 i 14/14) primjenjuje se na istraživanje i eksploataciju mineralnih sirovina koje se nalaze u zemlji ili na njezinoj površini, na riječnom, jezerskom ili morskom dnu ili ispod njega u unutarnjim morskim vodama ili teritorijalnom moru Republike Hrvatske ili u području epikontinentalnog pojasa Republike Hrvatske. Ovim Zakonom uređuje se gospodarenje mineralnim sirovinama i planiranje rudarske gospodarske djelatnosti, istraživanje i utvrđivanje rezervi mineralnih sirovina, izrada i provjera rudarskih projekata, eksploatacija mineralnih sirovina, davanje koncesije za eksploataciju, građenje i uporaba rudarskih objekata i postrojenja, izrada rudarskih planova i izvođenje rudarskih mjerenja, sanacija otkopanih prostora, naknada za koncesiju, naknada štete, mjere osiguranja, sigurnosti i zaštite, stručna sprema za obavljanje određenih poslova u rudarstvu, upravni i inspekcijski nadzor, prekršajne odredbe i druga pitanja (čl. 1).

11 Zakon o istraživanju i eksploataciji ugljikovodika primjenjuje se na istraživanje i eksploataciju ugljikovodika koji se nalaze u zemlji ili u podzemlju unutarnjih morskih voda ili teritorijalnog mora Republike Hrvatske, odnosno u podzemlju epikontinentalnog pojasa Jadranskog mora do linije razgraničenja sa susjednim zemljama na kojima Republika Hrvatska, u skladu s međunarodnim pravom, ostvaruje jurisdikciju i suverena prava. Čl. 1. propisuje da se ovim zakonom uređuje gospodarenje ugljikovodicima, istraživanje i eksploatacija ugljikovodika, izdavanje dozvole za istraživanje i sklapanje ugovora za eksploataciju, naknada, inspekcijski nadzor, prekršajne odredbe i druga pitanja.

12 Pomorski zakonik Republike Hrvatske N. N., br. 181/04, 76/07, 146/08, 61/11, 56/13, 26/15 (u nastavku rada-PZ). Odredbama ovoga Zakonika utvrđuju se morski i podmorski prostori Republike Hrvatske i uređuju pravni odnosi u njima, sigurnost plovidbe u unutarnjim morskim vodama i teritorijalnom moru Republike Hrvatske, zaštita i očuvanje prirodnih morskih bogatstava i morskog okoliša, osnovni materijalnopravni odnosi u pogledu plovnih objekata, ugovorni i drugi obvezni odnosi koji se odnose na brodove, upise plovnih objekata, ograničenje brodareve odgovornosti, ovrha i osiguranja na brodovima (čl. 1. PZ-a).

13 Zakon o zaštiti okoliša (N. N., br. 80/13, 153/13, 78/15) uređuje načela zaštite okoliša u okviru koncepta održivog razvitka, zaštitu sastavnica okoliša i zaštitu okoliša od utjecaja opterećenja, subjekte zaštite okoliša, dokumente održivog razvitka i zaštite okoliša, instrumente zaštite okoliša, praćenje stanja u okolišu, informacijski sustav zaštite okoliša, osiguranje pristupa informacijama o okolišu, sudjelovanje javnosti u pitanjima okoliša, osiguranje prava na pristup pravosuđu, odgovornost za štetu u okolišu, financiranje i instrumente opće politike zaštite okoliša, upravni i inspekcijski nadzor, te druga pitanja s tim u vezi.

14 Zakonom o osnivanju Agencije za ugljikovodike (N. N., br. 14/14) osniva se Agencija za ugljikovodike (u daljnjem tekstu: Agencija) kao pravna osoba s javnim ovlastima, koja samostalno i neovisno obavlja poslove u okviru djelokruga i nadležnosti određenih ovim Zakonom, Zakonom o istraživanju i eksploataciji ugljikovodika i drugim propisima koji uređuju ustrojstvo, prava, obveze i izvore sredstava Agencije. 
Dr. sc. Petra Amižić Jelovčić i Drago Kovačević: Hrvatski pravni okvir sigurnosti i zaštite morskog ... Zbornik radova Pravnog fakulteta u Splitu, god. 53, 2/2016., str. 469.-496.

i zaštiti pri istraživanju i eksploataciji ugljikovodika iz podmorja Republike Hrvatske ${ }^{15}$ te Plan intervencija kod iznenadnog onečišćenja mora. ${ }^{16}$

\section{ZAKON O SIGURNOSTI PRI ODOBALNOM ISTRAŽIVANJU I EKSPLOATACIJI UGLJIKOVODIKA}

Zakon o sigurnosti pri odobalnom istraživanju i eksploataciji ugljikovodika ${ }^{17}$ donesen je 3. srpnja 2015. godine, a na snazi je od 25. srpnja 2015. godine. Donošenjem ovog Zakona, Republika Hrvatska je, u cijelosti, uskladila nacionalno zakonodavstvo s pravom Europske unije u pogledu istraživanja i eksploatacije ugljikovodika u podmorju. Naime, Zakonom se u pravni sustav Republike Hrvatske prenosi Direktiva 2013/30/EU Europskog parlamenta i Vijeća o sigurnosti odobalnih naftnih i plinskih djelatnosti i o izmjeni direktive 2004/35/ EZ. ${ }^{18}$

Odobalno istraživanje i eksploatacija ugljikovodika obuhvaćaju sve aktivnosti $\mathrm{u}$ svezi $\mathrm{s}$ istraživanjem i eksploatacijom ugljikovodika, uključujući njihovo planiranje, projektiranje, izgradnju, rad i uklanjanje/sanaciju, ali isključujući transport ugljikovodika magistralnim cjevovodom ili plovnim objektom. Zakon u svom članku 1. propisuje područje primjene te navodi da će se njegove odredbe primjenjivati na odobalne objekte ${ }^{19}$ koji se nalaze ili plove u unutarnjim morskim

15 Pravilnikom o bitnim tehničkim zahtjevima, sigurnosti i zaštiti pri istraživanju i eksploataciji ugljikovodika iz podmorja Republike Hrvatske (N. N., br. 52/10) određuju se bitni tehnički zahtjevi, sigurnost i zaštita za radove koji se izvode u svrhu istraživanja i eksploatacije ugljikovodika iz podmorja Republike Hrvatske. Cilj navedenih zahtjeva jest tehničko-tehnološko izvođenje rudarskih radova na siguran način u skladu s odredbama Zakona o rudarstvu, Pomorskog zakonika, važećim normama i pravilima rudarske struke kojima se osigurava sigurnost i zaštita zdravlja ljudi, sprečava zagađivanje mora, morskog dna, podzemlja i zraka, sprečava neopravdano ometanje pomorskog i zračnog prometa, neopravdani ribolov, kao i sprečava uništavanje morske flore i faune.

16 O Planu intervencija kod iznenadnog onečišćenja mora opširnije vidi u poglavlju 3. ovog rada.

17 Zakon o sigurnosti pri odobalnom istraživanju i eksploataciji ugljikovodika (N. N., br. 78/15, u nastavku rada - Zakon).

18 Tekst direktive vidi: SL L 178, 28. 6. 2013. Članak 41. Direktive propisuje obvezu država članica na donošenje i objavu zakona i drugih propisa potrebnih za usklađivanje s navedenom Direktivom do 19. srpnja 2015. godine. Svrha je Direktive 2004/35/EZ o odgovornosti za okoliš u pogledu sprečavanja i otklanjanja štete u okolišu, utvrđivanje okvira za odgovornost za okoliš koji se temelji na načelu „onečišćivač plaća”, radi sprečavanja i otklanjanja štete u okolišu. Tekst direktive vidi: SL L 143/56, 21. 4. 2004. Zakonom se, također, osiguravaju pretpostavke za primjenu Provedbene uredbe Komisije (EU) br. 1112/2014 o utvrđivanju zajedničkog obrasca pomoću kojeg operateri $i$ vlasnici odobalnih naftnih $i$ plinskih objekata razmjenjuju informacije o pokazateljima velikih opasnosti te zajedničkog obrasca pomoću kojeg države članice objavljuju informacije o pokazateljima velikih opasnosti (SL L 302, 22. 10. 2014.).

19 Odobalni objekt znači nepomičan ili pomičan odobalni objekt s povezanom infrastrukturom koji se koristi za odobalno istraživanje, eksploataciju ugljikovodika i/ili u vezi s istim (čl. 4, t. 18 Zakona). Odredbe ovoga Zakona za postojeće odobalne objekte primjenjuju se od 19. srpnja 2018. Odredbe ovoga Zakona za planirane odobalne objekte primjenjuju se od 19. srpnja 2016. (čl. 40. Zakona). 
vodama ${ }^{20}$ i u teritorijalnom moru ${ }^{21}$ Republike Hrvatske, te u epikontinentskom pojasu Republike Hrvatske koji obuhvaća morsko dno i morsko podzemlje izvan vanjske granice teritorijalnog mora Republike Hrvatske u smjeru pučine do granice epikontinentalnog pojasa sa susjednim državama na kojima Republika Hrvatska, u skladu s međunarodnim pravom, ostvaruje jurisdikciju ${ }^{22}$ i suverena prava. ${ }^{23}$ Cilj koji se želi postići donošenjem ovoga Zakona jest stvaranje odgovarajuće pravne regulative koja bi trebala pridonijeti sprečavanju velikih nesreća tijekom odobalnog istraživanja i eksploatacije ugljikovodika, ali, ujedno, i urediti način primjene propisa, sprečavanja i postupanja u slučaju kada se dogode velike nesreće koje su povezane s izvođenjem odobalnih radova. ${ }^{24}$

Pod velikom nesrećom u odnosu na odobalni objekt ili povezanu infrastrukturu smatra se (čl. 4, t. 39 Zakona):

20 Unutrašnje morske vode jesu dijelovi mora između polazne crte od koje se mjeri širina teritorijalnog mora i obale. Obuhvaćaju morske prostore luka, zaljeva, ušća rijeka, zatvorenog mora, pod određenim uvjetima dijelove mora između otočnog niza i kontinentskog dijela kopna i između samih otoka. Širina unutrašnjih morskih voda nije ograničena jer ovisi o konfiguraciji i položaju obale i otoka. Unutrašnje su morske vode pod suverenošću obalne države jednako kao i njezino kopno. Davorin Rudolf, Enciklopedijski rječnik međunarodnog prava mora, Zagreb, 2012., str. 802.

21 Pod teritorijalnim morem smatra se pojas mora pod suverenošću obalne države umjerene širine (do 12 morskih milja) u kojemu strani brodovi imaju pravo neškodljivog prolaska. Pojas teritorijalnog mora mjeri se od polazne crte (normalne i ravne), a njegova vanjska granica ujedno je i državna granica na moru. Ibidem, str. 398-399.

22 Pod jurisdikcijom se u međunarodnom pravu mora podrazumijeva skupina ovlaštenja nekog subjekta međunarodnog prava. Za razliku od suverenosti, u istom području jurisdikciju mogu imati dvije države, pa i više njih, iako se njihova ovlaštenja mogu razlikovati i u opsegu i pojedinačno. U užem smislu jurisdikcija predstavlja ovlaštenja organa unutar jednog pravnog područja.

23 Suverena prava su prava koja izviru iz suverenosti, odnosno isključiva ili ekskluzivna prava. Termin je prvi put službeno unesen u međunarodno pravo mora na Prvoj konferenciji Ujedinjenih naroda o pravu mora 1958. godine. Navedena prava uključuju pravo nosioca na donošenje propisa, nadzor nad provedbom tih propisa i kažnjavanje zbog njihova kršenja, te poduzimanje svih mjera radi njihova ostvarivanja. Kao primjer suverenih prava mogu se navesti suverena prava radi iskorištavanja prirodnih bogatstava epikontinentalnog pojasa ili suvereno pravo radi njegova istraživanja. Za razliku od suverenih prava, suverenost označava teritorijalno vrhovništvo države nad osobama i stvarima na njezinu području. Suverenost jedne države na određenom prostoru isključuje suverenost druge države. Suverenost obalne države proteže se preko kopnenog dijela državnog područja i na obalno more (unutrašnje morske vode i teritorijano more), podmorje (dno i podzemlje) tog dijela mora te na zračni prostor iznad kopnenog dijela državnog područja i obalnog mora. Opširnije: Ibidem, str. 741.

24 Istragu velikih nesreća pokreće Ministarstvo gospodarstva, koje je nadležno za rudarstvo. Ono provodi istragu radi prikupljanja dokaza i podataka u svrhu primjerene analize velikih nesreća radi utvrđivanja njihovih uzroka, te osigurava pravodobno i točno izvješćivanje o rezultatima istrage $\mathrm{i}$ prijedlozima za poboljšanje stanja. Koordinacija za sigurnost pri odobalnom istraživanju i eksploataciji ugljikovodika dužna je sažetak rezultata provedene istrage dostaviti Europskoj komisiji te staviti javnosti na raspolaganje rezultate istrage koji nisu povjerljivi (čl. 28. Zakona). Zakon, također, uređuje i upravni i inspekcijski nadzor kao i prekršajne odredbe te druga pitanja (čl. 1, st. 2 Zakona). Upravni nadzor nad provedbom ovoga Zakona i propisa donesenih na temelju njega provodi Ministarstvo gospodarstva dok inspekcijski nadzor nad provedbom ovoga Zakona i propisa donesenih na temelju njega provodi rudarska inspekcija te druge inspekcije sukladno posebnim propisima. Ako rudarska inspekcija u obavljanju inspekcijskog nadzora utvrdi povredu odredbi ovoga Zakona ili propisa donesenih na temelju ovoga Zakona, osim mjera zabrane iz članka 35. ovoga Zakona, rješenjem će ovlašteniku dozvole narediti otklanjanje utvrđenih nedostataka, odnosno nepravilnosti u primjerenom roku, koji ne može biti duži od 90 dana. Opširnije o upravnom i inspekcijskom nadzoru vidi: čl. 35. i 36. Zakona. 
(a) nesreća koja uključuje eksploziju, požar, gubitak kontrole nad bušotinom ili nekontrolirano ispuštanje ugljikovodika ili opasnih tvari, ${ }^{25}$ a pritom uzrokuje gubitak života ili ozbiljne ozljede kod osoba ili postoji vjerojatnost uzrokovanja gubitka života ili ozbiljnih ozljeda, te onečišćenje i štete većih razmjera u okolišu na odobalnom području kao i na obalnom području kao posljedica onečišćenja,

(b) nesreća koja uzrokuje značajno oštećenje odobalnog objekta ili povezane infrastrukture, ${ }^{26}$ a pritom uzrokuje gubitak života ili ozbiljne ozljede kod osoba ili postoji vjerojatnost uzrokovanja gubitka života ili ozbiljnih ozljeda, te onečišćenje i štete većih razmjera u okolišu na odobalnom području kao i na obalnom području kao posljedica onečišćenja,

(c) bilo koja druga nesreća koja dovede do gubitka života ili ozljede kod pet ili više osoba istovremeno koje se nalaze na odobalnom objektu u kojem se pojavi izvor opasnosti ili koje sudjeluju u odobalnim radovima, te onečišćenje i štete većih razmjera u okolišu na odobalnom području kao i na obalnom području kao posljedica onečišćenja,

(d) događaj koji uzrokuje ili će vjerojatno uzrokovati bitan nepovoljan, odnosno negativan utjecaj na okoliš u skladu s propisima iz područja zaštite okoliša koji nastane kao posljedica nesreća iz točaka (a), (b) i (c). ${ }^{27}$

Pitanje sudjelovanja javnosti i zainteresirane javnosti (čl. 7. Zakona) ${ }^{28}$ jasno je regulirano te se izričito navodi da bušenje istražne bušotine ${ }^{29} \mathrm{~s}$ neeksploatacijskog objekta ${ }^{30}$ može započeti tek nakon što je osigurano rano i učinkovito sudjelovanje javnosti i zainteresirane javnosti. Međutim, propisivanje relativno kratkih rokova u st. 2 istog članka dovodi u pitanje mogućnost poštovanja zahtjeva za ranim i učinkovitim sudjelovanjem javnosti. ${ }^{31}$

25 Uredba o opasnim tvarima u vodama (N. N., br. 137/08) u svom čl. 2 definira opasne tvari u vodama kao tvari opasne za vodni okoliš koje se utvrđuju temeljem sljedećih kriterija: toksičnost, razgradljivosti i bioakumulacije i štetnost djelovanja na život i zdravlje ljudi i stanje okoliša i prirode. Također, u popisu opasnih tvari navodi ugljikovodike naftnog podrijetla.

26 Povezana infrastruktura znači bušotina s pripadajućom opremom, bilo koji dio odobalnog objekta ili bilo koji dio priključnih vodova unutar ili izvan sigurnosne zone odobalnog objekta (čl. 4, t. 26 Zakona).

${ }_{27}$ Za potrebe određivanja je li neka nesreća velika nesreća u smislu točaka (a), (b), (c) ili (d), s odobalnim objektom na kojem nema stalne posade postupa se kao da na njemu ima posade.

28 Javnost i zainteresirana javnost znači jednu ili više fizičkih ili pravnih osoba, njihove skupine, udruge i organizacije, u skladu s propisom kojim se uređuje zaštita okoliša (čl. 4, t. 12 Zakona). Zakon o zaštiti okoliša u svom čl. 4, t. 82 definira zainteresiranu javnost kao javnost na koju utječe ili bi moglo utjecati odlučivanje o okolišu ili ima interes u odlučivanju o okolišu; udruge civilnog društva koje djeluju na području zaštite okoliša i ispunjavaju sve uvjete sukladno ovom Zakonu.

29 Istražna bušotina jest bušotina čija je svrha istraživanje ležišta, određivanje geološkog profila, procjena rezervi i sl. Opširnije vidi: Boris Kavedžija, Tehnika izrade bušotina, www.rgn.hr/-bkave/ Materijali/1UVOD Idio.pdf

30 Neeksploatacijski objekt znači odobalni objekt koji se ne koristi za pridobivanje ugljikovodika (čl. 4, t. 16 Zakona).

31 Navedena obveza proizlazi iz Konvencije o pristupu informacijama, sudjelovanju javnosti u odlučivanju i pristupu pravosuđu u pitanjima okoliša (tzv. Arhuška konvencija). Potpisana 25. lipnja 1998. godine u danskom gradu Aarhusu, predstavlja međunarodni pravni okvir u području zaštite okoliša. Tim se dokumentom utvrđuju prava u vezi s okolišem kao pouzdana osnova za uključivanje građana $u$ politike okoliša te se potvrđuje naša obveza prema budućim generacijama. Republika Hrvatska ratificirala je konvenciju u prosincu 2007. godine (N. N. - M. U., br. 01/07). 
Zakon ističe dvije osobe koje imaju ključna prava i obveze sukladno njegovim odredbama. To su ovlaštenik dozvole i Koordinacija za sigurnost pri odobalnom istraživanju i eksploataciji ugljikovodika. Ovlaštenik dozvole jest pravna osobu kojoj je izdana dozvola za istraživanje i eksploataciju ugljikovodika, ${ }^{32}$ a koja je odgovorna za odobalne radove u smislu odredbi ovoga Zakona dok je Koordinacija za sigurnost pri odobalnom istraživanju i eksploataciji ugljikovodika nadležno tijelo imenovano u skladu s ovim Zakonom, a koje je nadležno za provedbu djelatnosti koje su nadležnom tijelu dodijeljene ovim Zakonom. Ovlaštenik dozvole može, u cijelosti ili djelomično, prenijeti prava i obveze iz dozvole samo na rudarski gospodarski subjekt ${ }^{33}$ koji ispunjava sve uvjete iz ovog Zakona i uvjete propisane relevantnim odredbama Europske unije. U tom smislu, dio prava i obveza može prijeći na operatera ili vlasnika.

Operater $^{34}$ ili vlasnik ${ }^{35}$ dužan je osigurati poduzimanje svih prikladnih mjera, sukladno ovom Zakonu, glede odobalnih radova ${ }^{36}$ kako bi se spriječile velike nesreće (čl. 5, st. 1 Zakona). Ukoliko bi, ipak, došlo do velike nesreće, dužni su poduzeti sve prikladne mjere kako bi ograničili njihove posljedice po zdravlje ljudi, okoliša, prirode i gospodarsku uporabu mora. Štoviše, oni odgovaraju i za radnje i propuste izvođača, ${ }^{37}$ koji su doveli ili doprinijeli velikim nesrećama.

Ipak, u pogledu naknade štete, ovlaštenik dozvole isključivo je financijski odgovoran za sprečavanje i sanaciju štete u okolišu i prirodi prouzročenu odobalnim radovima. Slijedom toga, ovlaštenik je dužan, za vrijeme trajanja izdane dozvole, imati i održavati na snazi odgovarajuće police osiguranja u skladu sa Zakonom

32 Sukladno odredbama Zakona o istraživanju i eksploataciji ugljikovodika, dozvolu za iskorištavanje i eksploataciju ugljikovodika izdaje Vlada Republike Hrvatske.

33 Zakon o istraživanju i eksploataciji ugljikovodika u svom čl. 4, t. 27. definira rudarski gospodarski subjekt kao jednu ili više pravnih osoba sa sjedištem ili podružnicom u Republici Hrvatskoj, registriranoj kod nadležnog tijela za obavljanje istraživanja i eksploatacije ugljikovodika kao i pravne osobe sa sjedištem u državama članicama Europske unije, registrirane za obavljanje istraživanja i eksploatacije ugljikovodika kod nadležnog tijela države članice Europske unije. Za potrebe trajnog zbrinjavanja plinova znači pravnu, privatnu ili javnu osobu koja eksploatira podzemno skladište ili ga kontrolira ili kojoj je u skladu s nacionalnim zakonodavstvom povjerena ovlast donošenja ekonomskih odluka o tehničkom funkcioniranju podzemnog skladišta.

34 Operater je operativna kompanija utvrđena ugovorom sklopljenim između ovlaštenika dozvole i Vlade Republike Hrvatske, u skladu sa Zakonom.

35 Vlasnik znači osobu koja je odgovorna za neeksploatacijski objekt (čl. 4, t. 41. Zakona).

36 Operater ili vlasnik dužni su osigurati obavljanje odobalnih radova na temelju sustavnog upravljanja rizikom, kako bi preostali rizici od velikih nesreća za zdravlje ljudi, okoliš, prirodu, gospodarsku uporabu mora i odobalne objekte bili prihvatljivi. Rizik je veličina koja se mjeri vjerojatnošću pojavljivanja događaja i potencijalom štete koju taj događaj može uzrokovati. Prihvatljiv rizik, pak, znači veličinu rizika kod kojeg bi vrijeme, trošak ili napor uloženi u njegovo smanjivanje bili uvelike nerazmjerni koristima od takvog smanjivanja rizika. Pri procjeni jesu li vrijeme, troškovi ili napori uvelike nerazmjerni koristima od daljnjeg smanjivanja rizika, mora se voditi računa o razinama rizika iz najbolje prakse koje su kompatibilne s operaterom ili vlasnikom (čl. 4, t. 29).

37 Izvođač znači bilo koju osobu s kojom operater ili vlasnik sklopi ugovor za izvođenje određenih radova u odobalnom istraživanju i eksploataciji ugljikovodika (čl. 4, t. 11. Zakona). O ugovorima o izvođenju radova bušenja pogledati opširnije: Ratko Brnabić - Marko Ivkošić, Ugovor o izvođenju radova bušenja u svezi s vađenjem nafte na moru (offshore drilling), Zbornik radova ,In memoriam prof. Dr. sc. Vjekoslav Šmid“", Rab, 2014., str. 92-128. 
o istraživanju i eksploataciji ugljikovodika, ${ }^{38}$ te poduzeti mjere kako bi osigurao da operater ili vlasnik ispunjavaju zahtjeve, izvršavaju svoje zadaće i dužnosti iz ovog Zakona prilikom izvođenja odobalnih radova. Nadzor nad radom operatera provodi Koordinacija koja će, ako utvrdi da operater više nije sposoban, ispunjavati zahtjeve iz ovog Zakona, te o istom obavijestiti Vladu Republike Hrvatske putem Ministarstva gospodarstva. Vlada će o tome obavijestiti ovlaštenika dozvole koji preuzima odgovornost za izvršavanje preuzetih obveza i koji će, bez odlaganja, u roku ne dužem od 30 dana, Vladi predložiti zamjenskog operatera.

\section{1. Koordinacija za sigurnost pri odobalnom istraživanju i eksploataciji ugljikovodika}

Odobalni radovi dozvoljeni su, isključivo, u području koje je obuhvaćeno dozvolom za istraživanje i eksploataciju ugljikovodika koju je izdala Vlada. Kako bi se osiguralo područje oko odobalnog objekta, Ministarstvo mora, prometa i infrastrukture odredit će oko njega sigurnosnu zonu u koju će biti zabranjen ulaz i zadržavanje određenim plovnim objektima (čl. 9. Zakona). ${ }^{39}$ Zakonom je propisana zabrana početka izvođenja radova dok Koordinacija za sigurnost pri

38 Zakon o istraživanju i eksploataciji ugljikovodika u svom čl. 43. ističe da je investitor obvezan, za vrijeme trajanja izdane dozvole i sklopljenog ugovora, imati i održavati na snazi odgovarajuće police osiguranja kojima se osiguravaju imovina investitora i trećih osoba, zdravlje i sigurnost radnika investitora i trećih osoba, ekološke štete, odnosno bilo koji drugi rizici koji mogu proizaći iz izvođenja rudarskih radova pri čemu je dužan poštovati važeće posebne propise iz područja osiguranja. Investitor se posebno obvezuje sklopiti police osiguranja kojima se osiguravaju bušotine, postrojenja, oprema, zgrade i druga nepokretna i pokretna imovina investitora; osiguravaju eventualne štete nastale u prirodi i okolišu, a koje se posebno odnose na onečišćenja zraka, vode, površine zemlje i područja ispod površine zemlje i to unutar i izvan istražnog prostora i/ili eksploatacijskog polja; osiguravaju eventualne štete nastale ispod površine zemlje (erupcija, gubitak geološkog sloja, gubitak rezervoara, onečišćenje na površini zbog erupcije, onečišćenje podzemnih voda i slično); općenito osigurava odgovornost investitora $\mathrm{i}$ to kako prema radnicima investitora tako i prema bilo kojim osobama angažiranima od strane investitora za izvođenje rudarskih radova i trećim osobama; općenito osigurava odgovornost za radnike investitora i bilo koje osobe angažirane od strane investitora za izvođenje rudarskih radova prema trećim osobama. Osim navedenih polica, obvezan je sklopiti police osiguranja sukladno posebnim propisima ako takve police već nisu obuhvaćene sadržajem iste odredbe. Ovlaštenik dozvole ima, dakle, obvezu sklapanja istovjetnih ugovora o osiguranju.

39 Zabrana se ne odnosi na osobe i plovne objekte koji ulaze ili se zadržavaju u sigurnosnoj zoni:

a) $\mathrm{u}$ vezi s polaganjem, ispitivanjem, popravkom, održavanjem, izmjenom, obnavljanjem ili uklanjanjem podvodnih vodova unutar ili u blizini sigurnosne zone;

b) radi pružanja usluga bilo kojem odobalnom objektu u toj sigurnosnoj zoni ili radi prijevoza osoba ili stvari na odobalni objekt ili s njega;

c) radi inspekcije bilo kojeg odobalnog objekta ili povezane infrastrukture u toj sigurnosnoj zoni prema propisima Republike Hrvatske;

d) u vezi sa spašavanjem ili pokušajem spašavanja života ili imovine;

e) u slučaju više sile ili nevolje na moru;

f) uz pristanak ovlaštenika dozvole, operatera, vlasnika, Koordinacije ili ostalih tijela javne vlasti;

g) radi provedbe interventnih mjera u slučajevima velike nesreće.

Ova je obveza propisana sukladno odredbi čl. 37. PZ-a koji propisuje da, na prijedlog izvođača radova na istraživanju i iskorištavanju bogatstava gospodarskog pojasa Republike Hrvatske, ministar može, kad je to potrebno, oko umjetnih otoka, uređaja i naprava ustanoviti sigurnosne zone široke do 500 metara mjereći od svake točke vanjskog ruba objekta, i u tim zonama zabraniti plovidbu. Uspostavljanje sigurnosne zone, njezina širina i režim plovidbe u njoj objavljuju se pravodobno u „Oglasu za pomorce“. 
odobalnom istraživanju i eksploataciji ugljikovodika ${ }^{40}$ ne prihvati izvješće o velikim opasnostima (čl. 8, st. 2. Zakona). ${ }^{41}$ Zakon razlikuje izvješće o velikim opasnostima za eksploatacijski objekt i za neeksploatacijski objekt. Izvješće za eksploatacijski objekt dužan je izraditi operater, a izvješće za neeksploatacijski objekt vlasnik. ${ }^{42}$ Treba naglasiti da prihvaćanje navedenog izvješća ni u kom slučaju ne znači i prijenos odgovornosti za velike nesreće s operatera ili vlasnika na Koordinaciju. ${ }^{43}$ Koordinacija je, međutim, odgovorna za niz radnji od kojih treba izdvojiti procjenu i prihvaćanje dokumenata ${ }^{44}$ koje je ovlaštenik dozvole dužan dostaviti Koordinaciji te ocjenu sposobnosti operatera u svezi s ispunjavanjem zahtjeva iz ovog Zakona. ${ }^{45}$

Koordinacija je tijelo koje mora biti neovisno i objektivno u obavljanju svojih djelatnosti te je dužno djelovati neovisno o politici. Međutim, kada se ima na umu da se Koordinacija sastoji od predstavnika Ministarstva, Agencije za ugljikovodike, Hrvatskog registra brodova, ministarstva nadležnog za pomorstvo, državne uprave nadležne za zaštitu i spašavanje, ministarstva nadležnog za zaštitu okoliša i prirode i Agencije za prostore ugrožene eksplozivnom atmosferom, javlja se sumnja u mogućnost realizacije zahtjeva za neovisnošću i objektivnošću iste. Naime, poznato je da je Agencija za uljikovodike tijelo nadležno za promicanje korištenja naftnih i plinskih resursa i kao takvo prilično pristrano te, samim tim, neadekvatno da bude uključeno u nadzor sigurnosti i zaštite okoliša pri istraživanju i eksploataciji ugljikovodika u našem podmorju.

Koordinacija mora svoju politiku, organizaciju i operativne postupke temeljiti na načelima transparentnosti, dosljednosti, razmjernosti i objektivnosti kod odobalnih radova. Također, dužna je jasno utvrditi opseg svojih odgovornosti kao i odgovornosti ovlaštenika dozvole, operatera, vlasnika i izvođača u pogledu nadzora nad rizicima od velike nesreće. Nadalje, mora utvrditi pravila, procese i postupke za temeljitu procjenu izvješća o velikim opasnostima i drugih dokumenata te ih učiniti dostupnima. ${ }^{46}$

Ovaj Zakon daje Koordinaciji nadležnost za provođenje niza radnji. Tako se u čl. 21. navodi izričito nadležnost Koordinacije da zatraži inspekcijski nadzor

40 U nastavku rada - Koordinacija. Organizaciju i način rada Koordinacije utvrđuje uredbom Vlada Republike Hrvatske na prijedlog Ministarstva. U roku od 15 dana od stupanja na snagu navedene Uredbe, Agencija je dužna na svojim mrežnim stranicama oglasiti opis organizacije, uključujući i razloge zbog kojih je Koordinacija uspostavljena na taj način, te način osiguranja izvršavanja djelatnosti (čl. 10) Vlada RH dužna je donijeti navedenu uredbu u roku od 6 mjeseci od stupanja na snagu ovog Zakona.

41 Velika opasnost znači situaciju koja može završti velikom nesrećom (čl. 4, toč. 40).

42 O informacijama koje trebaju sadržavati navdena izvješća pogledati: čl. 15. i 16. Zakona.

43 Prilikom procjene izvješća, Koordinacija je, između ostalog, dužna: utvrditi da su dostavljene sve tražene informacije; osigurati da su operater i vlasnik identificirali sve opasnosti od velikih nesreća koje se odnose na odobalne radove; utvrditi način provođenja mjera smanjivanja rizika; osigurati da su mjere i rješenja za otkrivanje, te brz i učinkovit odgovor u slučaju velike nesreće jasno prepoznati i opravdani...

44 Opširnije o tome vidi: čl. 13. Zakona i toč. 2.2. ovog rada.

45 Pored navedenog, Zakon propisuje odgovornost Koordinacije i za savjetovanje i suradnju s tijelima državne uprave i ostalim tijelima u skladu s odredbama ovog Zakona (čl. 11, st. 1).

46 Opširnije o dužnostima i nadležnosti Koordinacije vidi: čl. 12. i 21. Zakona. 
bilo kojeg odobalnog objekta ili povezane infrastrukture ako smatra da mjere predložene u izvješću o velikim opasnostima za sprečavanje ili ograničavanje posljedica velikih nesreća ili obavijestima o velikim radovima u bušotini ili simultanim operacijama ${ }^{47}$ koje su dostavljene u skladu s odredbama ovog Zakona, nisu dovoljne za ispunjavanje zahtjeva propisanih istim. Također, Koordinaciji je dana u nadležnost i odluka o skraćivanju vremenskog razmaka dostavljanja izvješća o velikim opasnostima ili drugih dokumenata kada smatra da su sigurnost te zaštita prirode i okoliša ugroženi.

Koordinacija je dužna utvrditi da su operater ili vlasnik izradili dokument u kojem određuju politiku za sprečavanje velikih nesreća ili odgovarajući opis te politike ${ }^{48}$ ali i osigurati njezinu primjenu tijekom čitavog trajanja odobalnih radova što uključuje uspostavljanje odgovarajućih režima praćenja s ciljem osiguranja učinkovitosti navedene politike. ${ }^{49}$ Spomenuti dokument mora sadržavati opće ciljeve i mjere nadzora nad rizikom od velike nesreće; odgovornost na razini upravnog odbora operatera ili vlasnika za kontinuirano osiguravanje prikladnosti, primjene i djelotvornosti politike za sprečavanje velikih nesreća; mjere za održavanje standarda sigurnosti i zaštite okoliša i prirode kao temeljne vrijednosti operatera ili vlasnika; sustave upravljanja i nadzora u koje su uključeni članovi upravnog odbora i viši upravitelji operatera ili vlasnika; stručnu osposobljenost na svim razinama operatera ili vlasnika... (čl. 22, st. 1.). Također, Koordinacija je dužna osigurati da dostavljena politika operatera ili vlasnika za sprečavanje velikih nesreća vodi računa o primarnoj odgovornosti operatera ili vlasnika za, između ostalog, nadzor nad rizicima od velike nesreće, te za trajno poboljšanje nadzora nad tim rizicima kako bi u svakom trenutku bila osigurana visoka razina zaštite. ${ }^{50} \mathrm{~S}$ istim ciljem, Koordinacija je dužna uspostaviti mehanizam za učinkovito sudjelovanje u tripartitnom savjetovanju između Koordinacije, operatera ili vlasnika, te predstavnika radnika oko oblikovanja normi i politika koje se odnose na sprečavanje velikih nesreća. ${ }^{51}$

47 Simultane operacije znače istovremeno izvođenje odobalnih radova $u$ svrhu istraživanja $i$ ekspoloatacije ugljikovodika na odobalnim objektima u skladu s propisom kojim su uređeni bitni tehnički zahtjevi, sigurnost i zaštita pri istraživanju i eksploataciji ugljikovodika iz podzemlja Republike Hrvatske, a iste operacije imaju bitni učinak na rizike za sigurnost osoba i zaštitu okoliša na nekom od odobalnih objekata ili na svim osobalnim objektima. O simultanim operacijma vidi opširnije: čl. 19. Zakona.

48 Dostavljena politika operatera ili vlasnika mora voditi računa o njihovoj primarnoj odgovornosti za nadzor nad rizicima od velike nesreće, te za trajno poboljšanje nadzora nad tim rizicima kako bi u svakom trenutku bila osigurana visoka razina zaštite. Navedena politika odnosi se i na odobalne objekte izvan Europske unije.

49 Koordinacija je dužna osigurati da operater ili vlasnik poduzmu prikladne mjere koje, prema potrebi, mogu uključivati zaustavljanje predmetne aktivnosti dok opasnost ili rizik ne bude pod odgovarajućim nadzorom u slučaju kada aktivnost koju obavlja operater ili vlasnik predstavlja neposrednu opasnost za zdravlje ljudi ili značajno povećava rizik od nesreće (čl. 22, st. 9). Štoviše, operater ili vlasnik dužan je, najkasnije 24 sata od poduzimanja navedenih mjera, putem ovlaštenika dozvole, obavijestiti Koordinaciju.

50 Štoviše, Koordinacija je dužna osigurati da operateri ili vlasnici postupaju u skladu s mjerama koje su utvrđene u dokumentima koji se dostavljaju u skladu s odredbama čl. 13. ovog Zakona.

51 Tripartitno savjetovanje znači formalni dogovor kojim se omogućuju dijalog i suradnja između Koordinacije, operatera ili vlasnika te predstavnika radnika (čl. 4, t. 37. Zakona). 
Pored navedenog, Koordinacija mora, u roku od 120 dana od dana stupanja na snagu Uredbe kojom se utvrđuje organizacija i način rada same Koordinacije, izraditi godišnje planove učinkovitog nadzora rizika koji se temelje na upravljanju rizicima i u kojima se posebno vodi briga o sukladnosti s izvješćem o velikim opasnostima i drugim dokumetima koje je ovlaštenik dozvole dužan dostaviti. ${ }^{52}$ Naposljetku, Koordinacija ima obvezu dostaviti Europskoj komisiji godišnje izvješće s podacima o broju, starosti i lokaciji odobalnih objekata te brojem i vrsti provedenih inspekcijskih nadzora $\mathrm{i}$ istraga. Izvješće mora sadržavati podatke o nesrećama, ${ }^{53}$ svim velikim promjenama regulatornog okvira koji se odnosi na odobalne radove i podatke o uspješnosti odobalnih radova u odnosu na sprečavanje velikih nesreća i ograničavanje posljedica velikih nesreća koje se ipak dogode. Prikupljena znanja, informacija i iskustva vezano za mjere za upravljanje rizicima, sprečavanje velikih nesreća, provjeru sukladnosti i odgovor na iznenadni događaj u pogledu odobalnih radova, Koordinacija je dužna redovito razmjenjivati s drugim nadležnim tijelima kroz Skupinu nadležnih tijela Europske unije za odobalne naftne i plinske aktivnosti, ${ }^{54}$ te sudjelovati u savjetovanjima o primjeni relevantnog nacionalnog zakonodavstva i zakonodavstva Europske unije s industrijom, drugim zainteresiranim stranama i Europskom komisijom.

\subsection{Ovlaštenik dozvole}

Istraživanje i eksploataciju ugljikovodika može obavljati samo osoba koja ima odgovarajuću dozvolu. Dozvola za istraživanje i eksploataciju ugljikovodika izdaje se podnositelju zahtjeva ${ }^{55} \mathrm{u}$ postupku javnog nadmetanja za izdavanje dozvole, tijekom kojeg se utvrđuje sposobnost podnositelja za ispunjavanje zahtjeva propisanih ovim Zakonom i uvjeta propisanih relevantnim odredbama prava Europske unije. ${ }^{56}$ Podnositelj zahtjeva izdavanjem dozvole za istraživanje i eksploataciju ugljikovodika postaje ovlaštenik dozvole.

Ovlaštenik dozvole dužan je dostaviti Koordinaciji: politiku operatera ili vlasnika za sprečavanje velikih nesreća ili odgovarajući opis te politike; pravila za upravljanje sigurnošću i zaštitom okoliša i prirode koja se odnose na odobalne objekte; obavijest o projektu vezano za eksploatacijski objekt; opis sustava

52 U istom je roku Koordinacija dužna uspostaviti mehanizme za povjerljivo izvješćivanje iz bilo kojeg izvora o zabrinutostima u pogledu sigurnosti, te zaštiti okoliša i prirode vezano za odobalne radove te za istragu prethodno spomenutih izvješća, pri čemu se čuva anonimnost pojedinaca. Agencija za ugljikovodike dužna je navedene mehanizme oglasiti na svojim mrežnim stranicama (čl. 24).

53 Koordinacija ima navedenu obvezu sukladno odredbi čl. 27. ovog Zakona.

54 Engl. The European Union Offshore Oil and Gas Authorities Group - EUOAG. Skupina je utemeljena Odlukom Komisije C 18/07 iz 2012. g.

55 Podnositelj zahtjeva je ponuditelj koji je predao ponudu na javnom nadmetanju za istraživanje $i$ eksploataciju ugljikovodika, u skladu s odredbama Zakona o istraživanju i eksploataciji ugljikovodika (čl. 4, t. 24).

56 Opširnije o uvjetima propisanima ovim Zakonom vidi: čl. 6, st. 3 Zakona. 
neovisne verifikacije ${ }^{57}$ izvješće o velikim opasnostima, ${ }^{58}$ Plan intervencija odobalnog objekta ${ }^{59}$ u slučaju radova u bušotini, obavijest i informacije o radovima u bušotini; ${ }^{60}$ obavijest o premještanju eksploatacijskog objekta ${ }^{61} \ldots$ Ovlaštenik je dužan pisanim putem, 30 dana prije predviđenog ulaska ili izlaska odobalnog objekta u područje na kojem Republika Hrvatska ostvaruje jurisdikciju i suverena prava, izvijestiti Koordinaciju koja, u roku od 5 dana od zaprimljene obavijesti, o istom mora obavijestiti tijela javne vlasti. ${ }^{62}$

Ovaj Zakon obvezuje ovlaštenika dozvole na ispunjenje, još jedne bitne obveze. Naime, on je dužan, bez odgode, obavijestiti Koordinaciju i Nacionalnu središnjicu za usklađivanje traganja i spašavanja na moru o (čl. 25. Zakona):

a) nekontroliranom ispuštanju ugljikovodika ili drugih opasnih tvari, zapaljivih i nezapaljivih tvari;

b) gubitku nadzora nad bušotinom koji zahtijeva aktivaciju primarnog zadržavanja i/ili sekundarnog zadržavanja, ili oštećenje integriteta bušotine koji zahtijeva remontne radove;

c) kvaru elementa koji je kritičan za sigurnost, te zaštitu okoliša i prirode; ${ }^{63}$

d) gubitku zaštite protiv učinaka požara ili eksplozije ili neželjeni pomak pomičnog odobalnog objekta;

e) opasnostima od plovila koja plove u smjeru sudara i stvarne sudare plovila s odobalnim objektima;

57 Neovisna verifikacija znači neovisnu procjenu i potvrdu valjanosti pisanih izjava, izvješća i ostale dokumentacije koju je izradio ovlaštenik dozvole, operater, vlasnik i/ili izvođač. Sustav za neovisnu verifikaciju mora biti uključen u sustav pravila za upravljanje sigurnošću i zaštitom okoliša i prirode koji se odnose na odobalne objekte. Rezultati neovisne verifikacije ne dovode u pitanje odgovornost operatera ili vlasnika za pravilno i sigurno funkcioniranje opreme i sustava koji se provjeravaju. Neovisni verifikator mora biti u potpunosti neovisan o Koordinaciji, operateru ili vlasniku, kao i ovlašteniku dozvole. Operater ili vlasnik dužni su obavijestiti neovisnog verifikatora o bitnim promjenama radi daljnje verifikacije u skladu sa sustavom neovisne verifikacije, a rezultati takve daljnje verifikacije dostavljaju se, putem ovlaštenika dozvole, Koordinaciji. Operateri i vlasnici obvezni su odgovoriti na preporuke neovisnog verifikatora i u skladu s njima poduzeti odgovarajuće mjere (čl. 20).

58 Izvješće je dužan dostaviti u roku koji odredi Koordinacija, a taj rok ne može biti duži od 30 dana prije planiranog početka odobalnih radova (čl. 13, st. 10).

59 Plan intervencija odobalnog objekta dužan je izraditi operater ili vlasnik. Plan intervencija odobalnog objekta mora biti dosljedan Planu intervencija kod iznenadnih onečišćenja mora (čl. 17. Zakona).

60 Ovlaštenik dozvole dužan je izraditi, u slučaju radova u bušotini, obavijest i informacije o tim radovima u bušotini i iste dostaviti 30 dana prije početka radova Koordinaciji. Koordinacija mora razmotriti obavijest i dati mišljenje temeljem kojega Ministarstvo izdaje suglasnost za početak radova u bušotini. Opširnije o tome vidi: čl. 18. Zakona.

${ }_{61}$ Ovlaštenik je dužan o tome obavijestiti Koordinaciju pisanim putem 45 dana prije predviđenog premještaja, kako bi tijekom izrade izvješća o velikim opasnostima, bio u mogućnosti uzeti u obzir sve uvjete i ograničenja koja postavi Koordinacija (čl. 13, st. 7).

62 Tijelo javne vlasti znači tijelo državne vlasti, tijelo jedinica lokalne i područne samouprave i pravne osobe s javnim ovlastima koje obavljaju djelatnosti u vezi s predmetom ovog zakona. U RH to je Agencija za ugljikovodike.

63 Elementi kritični za sigurnost, okoliš i prirodu znače dijelove odobalnih objekata, uključujući računalne programe, čija je svrha spriječiti ili ograničiti posljedice velike nesreće, a čiji bi kvar mogao ugroziti ili značajno doprinijeti velikoj nesreći (čl. 4, t. 5). 
Dr. sc. Petra Amižić Jelovčić i Drago Kovačević: Hrvatski pravni okvir sigurnosti i zaštite morskog ... Zbornik radova Pravnog fakulteta u Splitu, god. 53, 2/2016., str. 469.-496.

f) nesrećama u zračnom prometu na odobalnim objektima ili u blizini istih;

g) svim nesrećama sa smrtnim posljedicama;

h) svim ozbiljnim ozljedama pet ili više osoba u istoj nesreći;

i) svim obavljenim evakuacijama radnika;

j) svim iznenadnim događajima; ${ }^{64}$

k) svim velikim opasnostima; ${ }^{65}$

1) svim velikim nesrećama.

Navedene informacije moraju biti nedvosmislene i sastojati se od činjeničnih informacija te analitičkih podataka koji se odnose na odobalne radove. Pored navedenoga, moraju sadržavati i sve podatke određene za obavještavanje sukladno Planu intervencija kod iznenadnih onečišćenja mora ${ }^{66}$ Prema odredbama ovog Zakona, Plan intervencija kod iznenadnih onečišćenja mora donosi Vlada Republike Hrvatske, na prijedlog ministarstva nadležnog za zaštitu okoliša i prirode uz prethodno mišljenje Koordinacije. ${ }^{67}$ Koordinacija je dužna osigurati da je Plan intervencija odobalnog objekta usklađen s Planom intervencija kod

${ }^{64}$ Iznenadni događaj znači neželjeni, nenamjerni ili neočekivani događaj ili slijed takvih događaja, koji ima za posljedicu situaciju koja može završti velikom nesrećom, a koja uzrokuje ili će vjerojatno prouzročiti značajne nepovoljne učinke na okoliš i prirodu (čl. 4, t. 10).

${ }_{65}$ Operateri i vlasnici odobalnih objekata, počevši od 1. siječnja 2016., putem ovlaštenika dozvole dostavljaju izvješća, sukladno zajedničkom obrascu iz Provedbene uredbe Komisije (EU) br. 1112/2014, u roku ne dužem od deset radnih dana od dana događaja. Sukladno ovom obrascu, Koordinacija stavlja na raspolaganje javnosti informacije koje je Agencija dužna postaviti na svojim mrežnim stranicama i to, najkasnije, do 1. lipnja tekuće godine za prethodnu godinu (čl. 26. Zakona).

${ }^{6}$ Plan intervencija kod iznenadnih onečišćenja mora znači lokalni, nacionalni ili regionalni plan za sprečavanje širenja, odnosno ograničavanje posljedica velike nesreće povezane s odobalnim radovima. Navedeni planovi u Republici Hrvatskoj u smislu ovoga Zakona predstavljaju:

(a) za lokalnu/županijsku razinu županijski Plan intervencija u skladu s propisom donesenim na temelju odredbi Zakona o zaštiti okoliša i Pomorskog zakonika;

(b) za nacionalnu razinu Plan intervencija kod iznenadnih onečišćenja mora u skladu s propisom donesenim na temelju odredbi Zakona o zaštiti okoliša, Pomorskog zakonika i ovoga Zakona;

(c) za regionalnu razinu Sporazum o Subregionalnom planu intervencija za sprečavanje, spremnost za i reagiranje na iznenadna onečišćenja Jadranskog mora većih razmjera (N. N. - M. U., br. 7/08 u daljnjem tekstu: Subregionalni plan) i drugi međunarodni ugovori kojima se uređuje suradnja kod intervencija za sprečavanje, spremnost za i reagiranje na iznenadna onečišćenja Jadranskog mora većih razmjera (čl. 4, t. 23. Zakona).

67 Navedena odredba nije usuglašena s odredbom Zakona o zaštiti okoliša iz čl. 57. koji određuje da će Plan i njegove izmjene i dopune izraditi Ministarstvo u suradnji sa središnjim tijelima državne uprave nadležnima za poslove: pomorstva, unutarnjih poslova, vodnoga gospodarstva, vanjskih poslova, financija, obrane, ribarstva te zaštite i spašavanja, a donijet će ga Vlada. Spomenutu neusklađenost trebalo bi što skorije otkloniti. Republika Hrvatska obvezna je izraditi navedeni Plan temeljem međunarodno preuzetih obveza sukladno odredbama Međunarodne konvencije o pripravnosti, akciji i suradnji za slučaj onečišćenja uljem iz 1990. godine (engl. International Convention on Oil Pollution Preparedness, Response and Cooperation, OPRC 1990). Tako: Dorotea Corić, Onečišćenje mora s brodova međunarodna i nacionalna pravna regulativa, Rijeka, 2009., str. 96. Republika Hrvatska je ratificirala navedenu konvenciju (N. N. - M. U., br. 2/97), a za RH je stupila na snagu 12. 04. 1998. g. Vidi: Dragan Bolanča - Rajko Naprta, More naše plavo - Sigurnost plovidbe, zbirka propisa, Zagreb-Split, 2009., str. 443, Gordan Stanković, OPRC Konvencija - novo područje IMO-ove aktivnosti u borbi protiv zagađenja naftom, Uporedno pomorsko pravo, br. 127-128, Zagreb, 1990., str. 225-237. 
Dr. sc. Petra Amižić Jelovčić i Drago Kovačević: Hrvatski pravni okvir sigurnosti i zaštite morskog ... Zbornik radova Pravnog fakulteta u Splitu, god. 53, 2/2016., str. 469.-496.

iznenadnih onečišćenja mora, te osigurati izradu i ažuriranje Plana intervencija kod iznenadnih onečišćenja mora.

\section{PLAN INTERVENCIJA KOD IZNENADNIH ONEČIŠĆENJA MORA}

Plan intervencija kod iznenadnih onečišćenja mora jest dokument održivog razvitka i zaštite okoliša kojim se utvrđuju postupci i mjere za predviđanje, sprečavanje, ograničavanje, spremnost za i reagiranje na iznenadna onečišćenja mora i na izvanredne prirodne događaje u moru radi zaštite morskog okoliša, a koji je usklađen s međunarodnim ugovorima iz područja zaštite morskog okoliša čija je stranka Republika Hrvatska (čl. 1. Plana intervencija kod iznenadnih onečišćenja mora). ${ }^{68}$ Primjenjuje se kod iznenadnog onečišćenja mora uljem i/ ili smjesom ulja razmjera većeg od $2000 \mathrm{~m}^{3}$ opasnim i štetnim tvarima, ${ }^{69}$ te kod izvanrednih prirodnih događaja u moru. ${ }^{70} \mathrm{Za}$ onečišćenja uljem i/ili smjesom ulja razmjera manjeg od $2000 \mathrm{~m}^{3}$, za manji opseg i jačinu izvanrednog prirodnog događaja u moru, primjenjuje se županijski plan intervencija kod iznenadnih onečišćenja mora koji, uz prethodnu suglasnost središnjeg tijela državne uprave za zaštitu okoliša, donosi predstavničko tijelo županije.

Plan intervencija primjenjuje se na morske prostore, na dno i podmorje Republike Hrvatske, koji obuhvaćaju pomorsko dobro, unutarnje morske vode, teritorijalno more i zaštićeni ekološko-ribolovni pojas. Prednost u provedbi ovog Plana imaju zaštićena područja mora i uzgajališta marikulture. Zapovjednik Stožera za provedbu Plana intervencija donosi odluku o prestanku djelovanja po Planu intervencija kada su mjere djelovanja po Planu intervencija obavljene te je prestala ugroza morskog okoliša i kada očekivani rezultati mjera postupanja po Planu intervencija mogu biti štetniji od samog onečišćenja mora.

68 Vlada Republike Hrvatske, na temelju članka 50, stavka 4. Zakona o zaštiti okoliša (Narodne novine, broj 110/2007) i članka 63, stavka 2. Pomorskog zakonika (Narodne novine, br. 181/2004 i 76/2007), donijela je na sjednici održanoj 31. srpnja 2008. godine Plan intervencija kod iznenadnih onečišćenja mora (N. N., br. 92/08 - u nastavku rada: Plan intervencija). Kasnijim je izmenama PZ-a čl. 63, st. 2. koji je propisivao ovlast Vlade za donošenje Plana intervencija brisan.

69 Opasne i štetne tvari su svaka tvar, osim ulja, koja može, ako se unese u morski okoliš, ugroziti zdravlje ljudi, nanijeti štetu morskom okolišu, nanijeti štetu privlačnosti morskog okoliša ili ometati druge dopuštene načine korištenja mora.

70 Izvanredni prirodni događaj u moru jest prirodna pojava koja nastaje uslijed prekomjernog rasta broja određenih morskih organizama, kao što su alge, meduze i slično. Radi se, dakle, o biloškom onečišćenju mora. Najčešći izvor biološkog onečišćenja mora jest nepropisna izmjena balastnih voda. $\mathrm{O}$ tome vidi: Petra Amižić Jelovčić, „Onečišćenje morskog okoliša balastnim vodama s posebnim osvrtom na međunarodnu konvenciju o nadzoru i upravljanju brodskim balastnim vodama i talozima iz 2004. godine“, Zbornik Pravnog fakulteta u Splitu, br. 4, Split, 2008., str. 797-810. 
Plan intervencija financira se iz Državnog proračuna ${ }^{71}$ na pozicijama središnjih tijela državne uprave nadležnih za more, zaštitu okoliša, zaštitu prirode i kulturne baštine te iz naknada za troškove od onečišćenja po poznatom onečišćivaču. ${ }^{72}$ Plan izričito navodi da će se zahtjev za naknadu štete zbog onečišćenja morskog okoliša koju prouzroči plovni objekt koji prevozi ulje i/ili smjesu ulja, podnijeti protiv vlasnika broda na temelju Pomorskog zakonika, Međunarodne konvencije o građanskoj odgovornosti za štetu zbog onečišćenja uljem i Međunarodne konvencije o osnivanju međunarodnog fonda za naknadu štete uzrokovane onečišćenjem uljem. ${ }^{73}$

U smislu odredbi ovog Plana treba razlikovati pojam iznenadnog onečišćenja mora od pojma izvanrednog prirodnog događaja u moru. Iznenadno onečišćenje mora jest događaj ili niz događaja istog podrijetla koji izazivaju ili mogu izazvati ispuštanje ulja i/ili smjese ulja, ${ }^{74}$ opasnih i štetnih tvari i koji predstavljaju ili mogu predstavljati opasnost za morski okoliš ili obalu, te koji zahtijevaju djelovanje u slučaju opasnosti ili drugo trenutačno reagiranje. S druge strane, izvanredni prirodni događaj u moru jest prirodna pojava koja nastaje uslijed prekomjernog rasta broja određenih morskih organizama, kao što su alge, meduze i slično.

Plan intervencija u svom članku 1.1. taksativno navodi što će se smatrati rizikom, odnosno prijetnjom od onečišćenja okoliša. ${ }^{75}$ Pored nezgoda na odobalnim pomorskim objektima, koje su nama zbog teme ovog rada posebno zanimljive, pod navedeno ubraja:

71 Iz sredstava državnog proračuna financiraju se

- gradnja i održavanje brodova čistača mora,

- troškovi dijela hladnog pogona brodova čistača mora,

- troškovi administrativnih poslova i logističke potpore Stožera,

- troškovi izobrazbe na nacionalnoj i međunarodnoj razini,

- troškovi za zajednička reagiranja prema Subregionalnom planu,

- troškovi poduzimanja žurnih mjera kada je onečišćivač nepoznat,

- troškovi za otklanjanje onečišćenja kod izvanrednih prirodnih događaja u moru itd.

72 Onečišćivač snosi troškove nastale onečišćenjem morskog okoliša. Troškovi obuhvaćaju:

- troškove zaštitnih mjera,

- troškove procjene onečišćenja,

- troškove uzorkovanja i analize mora i po potrebi zraka uslijed onečišćenja,

- troškove razumnih mjera,

- naknadu troškova koji se mogu odrediti za štetu nastalu na zaštićenim prirodnim vrijednostima,

- naknadu za oštećenje imovine subjekata u provedbi Plana intervencija.

73 Opširnije o konvencijama vidi: Dorotea Ćorić, Međunarodni sustav odgovornosti i naknade štete zbog onečišćenja mora uljem, Zagreb, 2002., str. 9-71, Ćorić, D., Onečišćenje mora s brodova..., o.c., str. 128-150.

74 Pod uljem misli se na sva postojana ugljikova mineralna ulja, kao što su sirova nafta i njezini derivati, te talozi i otpadna ulja iz Priloga I. Međunarodne konvencije o sprečavanju zagađivanja mora $\mathrm{s}$ brodova, kako je izmijenjena i dopunjena, bez obzira na to prevoze li se kao teret ili kao zalihe goriva $\mathrm{i}$ maziva, dok je Smjesa ulja smjesa s bilo kakvim sadržajem ulja.

75 Pod vrstama rizika i prijetnji od onečišćenja mora podrazumijevaju se mogući događaji ili situacije koje mogu prouzročiti štetu u morskom okolišu. 
- nezgode na moru koje uključuju sudar brodova, nasukavanje, požar, eksploziju, kvar na konstrukciji, nezgodu pri upravljanju brodom ili drugi događaj na brodu ili izvan njega,

- nezgode na podmorskim cjevovodima, - potonule brodove ${ }^{76}$ i zrakoplove,

- izvanredne prirodne događaje u moru,

- pad zrakoplova i helikoptera u more,

- nezgode na obalnim instalacijama i terminalima.

\subsection{Subjekti za provedbu Plana intervencija}

Subjekti koji sudjeluju u provedbi Plana intervencija jesu Stožer za provedbu Plana intervencija, Nacionalna središnjica za usklađivanje traganja i spašavanja na moru u Rijeci i Županijski operativni centar. Stožer ${ }^{77}$ je tijelo odgovorno za provedbu postupaka i mjera predviđanja, sprečavanja, ograničavanja, spremnosti za i reagiranja po Planu intervencija i Subregionalnom planu. ${ }^{78}$ Njegove glavne zadaće su, između ostalog: zapovjedno djelovanje po Planu intervencija, donošenje odluke o aktiviranju i završetku djelovanja po Planu intervencija odnosno o aktiviranju i završetku koordinativnog djelovanja Nacionalne središnjice za usklađivanje traganja i spašavanja na moru, provedba mjera sprečavanja onečišćenja mora, aktiviranje raspoloživih tehničkih i ljudskih resursa Obalne straže ${ }^{79}$ prikupljanje dokaza i dokumenata u svrhu potraživanja naknade štete

76 Potonuli brodovi smatraju se podrtinama. Prema definiciji Međunarodne konvencije o uklanjanju podrtina iz 2007. godine, podrtina je ne samo potonuli ili nasukani brod, već i bilo koji dio potonulog ili nasukanog broda, uključujući svaki predmet koji se nalazi ili se nalazio na tom brodu ili je nestao u moru s broda koji je nasukan, potonuo ili ostavljen da pluta. U opseg pojma podrtine ulazi i brod koji će uskoro potonuti ili se nasukati, ili se to opravdano može očekivati, ukoliko još nisu poduzete učinkovite mjere radi pomoći brodu ili bilo kojoj imovini u opasnosti. Više o tome: Vesna Skorupan Wolff - Ranka Petrinović, „Međunarodna konvencija o uklanjanju podrtina“, Poredbeno pomorsko pravo, br. 162, Zagreb, 2008., str. 109-134.

77 Sastav Stožera:

- članove i zamjenike članova Stožera imenuje Vlada Republike Hrvatske iz redova središnjih tijela državne uprave nadležnih za: more, zaštitu okoliša, zaštitu prirode, unutarnje poslove, vodno gospodarstvo, vanjske poslove, financije, zaštitu i spašavanje, obranu i predstavnike Nacionalne središnjice za usklađivanje traganja i spašavanja na moru,

- zapovjednik Stožera je predstavnik središnjeg tijela državne uprave nadležnog za more,

- zamjenik zapovjednika Stožera je voditelj Nacionalne središnjice za usklađivanje traganja i spašavanja na moru,

- tajnik Stožera je predstavnik središnjeg tijela državne uprave nadležnog za more,

- uže zapovjedništvo Stožera čine predstavnici središnjih tijela državne uprave nadležnih za more, zaštitu okoliša, zaštitu i spašavanje, unutarnje poslove, obranu i predstavnik Nacionalne središnjice za usklađivanje traganja i spašavanja na moru.

78 Subregionalni plan intervencija za sprečavanje, spremnost za i reagiranje na iznenadna onečišćenja Jadranskog mora većih razmjera jest plan intervencija kojemu je cilj uspostaviti mehanizam međusobne suradnje pomoću kojeg će nadležna nacionalna tijela jadranskih država surađivati radi usklađivanja i objedinjavanja svojih djelovanja koja se odnose na sprečavanje i reagiranje na iznenadna onečišćenja mora, a koja utječu ili bi mogla utjecati na teritorijalno more, obale i povezane interese jedne ili više jadranskih država, ili na nezgode koje prelaze raspoloživu sposobnost za reagiranje svake države pojedinačno.

79 Obalna straža može za potrebe Plana intervencija angažirati pravne osobe specijalizirane za intervencije na otvorenom moru (tegljenje, gašenje požara, postavljanje brana i drugo) radi provođenja 
po okončanju intervencije, donošenje odluke o načinu uklanjanja onečišćenja, traženje pomoći drugih država, odnosno traženje pomoći od REMPEC-a ${ }^{80}$ putem Nacionalne središnjice za usklađivanje traganja i spašavanja na moru, aktiviranje Subregionalnog plana, te koordiniranje operacijama zajedničkog reagiranja prema Subregionalnom planu, informiranje javnosti...

Ako onečišćenje opasnim i štetnim tvarima ili izvanrednim prirodnim događajem u moru može ugroziti morski okoliš, zdravlje ljudi i gospodarsku uporabu mora i može imati posljedice za dvije ili više županija ili kada je količina onečišćenja uljem i/ili smjesom ulja veća od $2000 \mathrm{~m}^{3}$, zapovjedno djelovanje provodi Stožer, a koordinativno djelovanje Nacionalna središnjica za usklađivanje traganja i spašavanja na moru u suradnji sa županijskim operativnim centrima. Nadzor nad operativnim djelovanjem po Planu intervencija na mjestu onečišćenja provode nadležni inspektor lučke kapetanije i inspektor zaštite okoliša.

Nacionalna središnjica za usklađivanje traganja i spašavanja na moru ${ }^{81}$ jest tijelo nadležno za koordinaciju Stožera i županijskih operativnih centara u slučaju iznenadnih onečišćenja mora u Republici Hrvatskoj. MRCC je zadužen za: operativno djelovanje po Planu intervencija, koordinativno djelovanje po županijskim planovima intervencija, koordiniranje provedbe mjera sprečavanja onečišćenja mora, aktiviranje ljudstva, raspoložive opreme i sredstava s kopna, mora i zraka po nalogu zapovjednika Stožera, održavanje veza i usklađivanje rada svih osoba koje sudjeluju u djelovanju, za razmjenu informacija s nadležnim županijskim centrima 112 uključenima u provedbu Plana intervencija i županijskih planova intervencija, izvješćivanje Stožera o tijeku djelovanja, obavješćivanje operativnih tijela drugih država i REMPEC-a o mogućem/nastalom onečišćenju mora putem Sustava informiranja o onečišćenju ${ }^{82} \ldots$ Plan intervencija razlikuje nekoliko slučajeva djelovanja MRCC-a te tako ističe situaciju kada onečišćenje mora može ugroziti morski okoliš, zdravlje ljudi ili gospodarsku uporabu mora u području više županijskih operativnih centara, ili prelazi mogućnost djelovanja jednog županijskog operativnog centra, koordinativnog županijskog operativnog

mjera sprečavanja i ograničavanja onečišćenja mora te interventnih mjera kod onečišćenja mora po nalogu zapovjednika Stožera. Način suradnje Obalne straže Republike Hrvatske s tijelima nadležnima za nadzor iznenadnog onečišćenja na moru propisan je Pravilnikom o suradnji Obalne straže s tijelima nadležnima za nadzor kod iznenadnog onečišćenja mora (N. N., br. 153/09). Više o tome vidi: Petra Amižić Jelovčić Željka Primorac - Nikola Mandić, „Pravni aspekt organizacije i djelokruga rada Obalne straže u Republici Hrvatskoj s posebnim osvrtom na Zakon o Obalnoj straži“, Poredbeno pomorsko pravo - Izazovi $i$ perspektive u pomorskom pravu i pravu mora: Interesi RH, br. 164., Zagreb, 2010., str. 367-425, Petra Amižić Jelovčić - Željka Primorac - Nikola Mandić, „Obalna straža i zaštita prava i interesa Republike Hrvatske na moru“, Zbornik radova sa znanstveno-stručnog skupa In memoriam prof. dr. sc. Vjekoslav Šmid, Split, 2012., str. 37-59.

80 REMPEC jest Regionalni centar za žurne intervencije u slučaju onečišćenja Sredozemnog mora (engl. Regional Marine Pollution Emergency Responce Centre), osnovan na temelju 7. Rezolucije Barcelonske konvencije 1976. Ima sjedište u Malti. REMPEC je izradio Subregionalni plan intervencija kod iznenadnih onečišćenja Jadranskog mora za Hrvatsku, Italiju i Sloveniju čija je izrada inicirana u okviru trilateralne hrvatsko-talijansko-slovenske suradnje na zaštiti Jadrana. Vidi: Ćorić, D., Onečišćenje mora s brodova..., o.c., str. 65.

81 U nastavku rada - MRCC. Ima sjedište u Rijeci.

82 Engl. The Standard Format Pollution Report (u daljnjem tekstu - POLREP). 
centra, gdje propisuje koordinativu MRCC-a, a operativno djelovanje županijskih operativnih centara. ${ }^{83} \mathrm{U}$ slučaju, pak, onečišćenja u ZERP-u, a po potrebi i u teritorijalnom moru i unutarnjim morskim vodama, MRCC predlaže Stožeru aktiviranje Obalne straže.

Županijski operativni centar ${ }^{84}$ jest tijelo odgovorno za provedbu postupaka i mjera predviđanja, sprečavanja, ograničavanja, spremnosti za i reagiranja po županijskom planu intervencija i za operativno sudjelovanje u provedbi Plana intervencija i Subregionalnog plana. ${ }^{85} \mathrm{U}$ glavne zadatke ŽOC-a ubrajaju se: operativno djelovanje prema Planu intervencija po nalogu Stožera, provedba županijskog plana intervencija kod iznenadnih onečišćenja mora, provedba mjera sprečavanja onečišćenja mora, procjena opsega i jačine onečišćenja mora, obavješćivanje Stožera o nastalim onečišćenjima i poduzetim mjerama za sprečavanje i reagiranje, aktiviranje ljudstva, raspoložive opreme i sredstava s kopna, mora i zraka.... Ako onečišćenje ugrožava ili može ugroziti morski okoliš, zdravlje ljudiili gospodarsku uporabu mora u području djelovanjaŽOC-a, te ukoliko količina onečišćenja uljem i/ili smjesom ulja iznosi do $2000 \mathrm{~m}^{3}$ i za manji opseg i jačinu izvanrednog prirodnog događaja djelovanje je u nadležnosti tog ŽOC-a. Ako onečišćenje ugrožava ili može ugroziti morski okoliš, zdravlje ljudi ili gospodarsku uporabu mora u području djelovanja više ŽOC-eva, ili prelazi mogućnost djelovanja jednog ŽOC-a, koordinativno djelovanje preuzima MRCC u suradnji sa ŽOC-em Primorsko-goranske županije odnosno ŽOC-em Splitsko-dalmatinske županije. Nadzor nad operativnim djelovanjem po županijskim planovima intervencija na mjestu onečišćenja provode nadležni inspektor lučke kapetanije i inspektor zaštite okoliša.

Plan sadržava postupke za predviđanje i mjere za sprečavanje i ograničavanje onečišćenja mora te postupke i mjere reagiranja za smanjenje šteta u morskom okolišu. Provođenjem postupaka za predviđanje ${ }^{86}$ i mjerama za sprečavanje

83 To su županijski operativni centri Primorsko-goranske županije za područje Istarske, Primorskogoranske, Ličko-senjske i Zadarske županije odnosno županijskog operativnog centra Splitsko-dalmatinske županije za područje Šibensko-kninske, Splitsko-dalmatinske i Dubrovačko-neretvanske županije.

${ }^{84}$ U nastavku rada - ŽOC. Područje djelovanja županijskog plana intervencija odgovara granicama županije.

85 Sastav ŽOC-a:

- članove i zamjenike članova ŽOC-a imenuje župan iz redova upravnih tijela županije nadležnih za poslove zaštite mora, zaštite okoliša, zaštite i spašavanja, te unutarnjih poslova, predstavnika lučke kapetanije i iz redova znanstvenih i stručnih institucija,

- zapovjednik ŽOC-a je lučki kapetan,

- zamjenik zapovjednika ŽOC-a je predstavnik županijske Policijske uprave - Sektora za granicu, - uže zapovjedništvo ŽOC-a čine predstavnici upravnih tijela županije nadležnih za poslove zaštite more, zaštitu okoliša, zaštitu i spašavanje, te unutarnjih poslova.

Sjedište ŽOC-a nalazi se u lučkoj kapetaniji.

86 Postupci za predviđanje obuhvaćaju: praćenje stanja morskog okoliša, proglašavanje i upravljanje područjima posebno osjetljivog mora, osiguranje sustava za nadzor pomorskog prometa, osiguranje tehničkih sredstava i službi za provedbu mjera sprečavanja i ograničavanja onečišćenja mora, procjenu rizika i osjetljivosti područja djelovanja Plana intervencija. 
Dr. sc. Petra Amižić Jelovčić i Drago Kovačević: Hrvatski pravni okvir sigurnosti i zaštite morskog ... Zbornik radova Pravnog fakulteta u Splitu, god. 53, 2/2016., str. 469.-496.

i ograničavanje onečišćenja mora ${ }^{87}$ ispunjava se zahtjev sadržan u načelu prevencije. $^{88}$

Pored subjekata, sukladno odredbama Plana intervencija, na prevenciji i ograničavanju onečišćenja morskog okoliša prilikom odobalnih radnji trebaju raditi i operater ili vlasnik. Oni su, naime, dužni redovito ispitivati pripravnost za učinkovit odgovor na velike nesreće samostalno, te sudjelovati u ispitivanjima pripravnosti i vježbama Koordinacije i Stožera ${ }^{89}$ Operater ili vlasnik dužan je bez odgađanja obavijestiti Koordinaciju i MRCC o iznenadnim događajima, velikim nesrećama ili velikim opasnostima te su dužni poduzeti sve mjere propisane Zakonom kako bi spriječili daljnje širenje nesreće i ograničili njezine posljedice, kao i pružati podatke, stručnu i tehničku potporu subjektima nadležnima za koordinaciju u skladu s Planom intervencija.

\section{2. Postupci i mjere reagiranja za smanjenje šteta u morskom okolišu}

Ako prijeti opasnost od onečišćenja s pomorskog objekta odgovorna osoba za taj objekt dužna je o tome obavijestiti MRCC. Tko prouzroči ili primijeti onečišćenje mora ili nezgodu koja može prouzročiti onečišćenje mora, dužan je odmah o tome obavijestiti županijski centar 112, lučku kapetaniju ili njezine ispostave. Službena osoba koja zaprimi obavijest dužna je informaciju proslijediti MRCC-u. Službena osoba u MRCC-u, nakon primitka obavijesti o onečišćenju mora odnosno o nezgodi koja može prouzročiti onečišćenje mora, dužna je od odgovorne osobe na pomorskom objektu zatražiti podatke o: vrsti nezgode, vrsti, veličini i nazivu, broju osoba na objektu, vlasniku/korisniku objekta, agentu objekta u Republici Hrvatskoj, točnoj poziciji, stupnju opasnosti za ljudski život, podatke o ozlijeđenima i mogućnosti pomoći ozlijeđenima, o vrsti tereta i spremnicima, te informacije o njihovoj opasnosti po morski okoliš, veličini oštećenja objekta, poduzetim aktivnostima na otklanjanju prijetnji i mogućih posljedica.

Nakon prikupljenih i obrađenih podataka o onečišćenju mora odnosno nezgodi koja može prouzročiti onečišćenje mora, MRCC dostavlja izvješće o nezgodi središnjim tijelima državne uprave nadležnima za more, zaštitu okoliša i unutarnje poslove, ${ }^{90}$ ŽOC-u, županijskom centru 112 i Obalnoj straži. Po primitku izvješća o nezgodi, radi utvrđivanja opsega i vrste onečišćenja i procjene situacije, zapovjednik ZOC-a osigurava izviđanje i praćenje kretanja onečišćenja

87 Mjere sprečavanja i ograničavanja obuhvaćaju: utvrđivanje, smanjivanje i uklanjanje opasnosti od onečišćenja mora. Za komunikaciju u slučaju onečišćenja koristi se VHF kanal 16, 10.

88 Načelo obuhvaća slučajeve manje vjerojatnosti štete, sve do sumnje u postojanje opasnosti. Djelovanje uskladu s navedenim načelom od neprocjenjive je važnosti za zaštitu okoliša s obzirom na to da je općepoznato da pravodobna prevencija djeluje dugoročno. Olivera Lončarić Horvat i dr., Osnove prava okoliša, Zagreb, 1997., str. 34.

89 Ovlaštenik dozvole dužan je izvješće o ispitivanju pripravnosti dostaviti Koordinaciji u roku ne dužem od pet dana od dana kada se završilo ispitivanje pripravnosti (čl. 31. Zakona).

90 Misli se na dostavu izvješća o nezgodi nadležnim ministarstvima. 
na površini mora zrakoplovom ili helikopterom. Temeljem izvješća o nezgodi i procjene situacije, aktivira se plan intervencija odgovarajuće razine. ${ }^{91}$

Plan intervencija kod iznenadnih onečišćenja mora također sadržava postupke za odgovor na veliku nesreću koja nadilazi mogućnosti Republike Hrvatske ili prelazi izvan njezinih granica. Nacionalno tijelo odgovorno za provedbu Subregionalnog plana jest Stožer, ${ }^{92}$ a centar za reagiranje/zajedničko reagiranje u slučaju opasnosti je MRCC.

Ako onečišćenje može ugroziti teritorijalna mora i područja interesa drugih država, Stožer odmah obavještava operativna tijela drugih država i REMPEC putem MRCC-a i to kada se dogodi nezgoda:

- na području odgovornosti Republike Hrvatske koja može prouzročiti onečišćenje ili je došlo do onečišćenja područja druge države,

- izvan područja odgovornosti Republike Hrvatske, a postoji prijeteća opasnost za područje odgovornosti Republike Hrvatske, prema procjeni Stožera,

- na području odgovornosti Republike Hrvatske, a opseg djelovanja zahtijeva uključivanje osoblja i/ili tehničkih/materijalnih sredstava i opreme koji prema procjeni Stožera prelaze mogućnosti reagiranja Republike Hrvatske.

Nakon zatražene pomoći, Republika Hrvatska može odobriti ulazak i djelovanje osoblja, plovnih objekata u unutarnjim morskim vodama, teritorijalnom moru, ZERP-u i zrakoplova u hrvatskom zračnom prostoru za potrebe nadziranja onečišćenja, sprečavanja širenja i skupljanje izlivenog ulja te opasnih i štetnih tvari, uzorkovanje i analize mora i zraka, uporabe disperzanata ili drugih proizvoda za obradu onečišćenog područja, skladištenje i prijevoz skupljenog opasnog otpada te prijevoza osoblja, tehničkih/materijalnih sredstava i opreme za pružanje pomoći.

Plan detaljno propisuje provedbu interventnih mjera kod iznenadnih onečišćenja mora. Pritom, razlikuje postupke u slučaju izlijevanja ulja i/ili smjese ulja, u slučaju onečišćenja opasnim i štetnim tvarima i u slučaju izvanrednog prirodnog događaja u moru. ${ }^{93}$ Kada je došlo do izlijevanja ulja i/ili smjese ulja, zapovjednik Stožera ili zapovjednik ŽOC-a, ovisno o količini izlivenog ulja i/ili smjese ulja, odlučuje o načinu izviđanja i praćenja kretanja ulja i/ili smjese ulja na površini mora, odnosno morskoj obali. Izviđanje se obavlja iz zraka, a ako to

91 Zapovjednik ŽOC-a i MRCC-a odnosno osoba koju zapovjednik zaduži, odgovorna je za vođenje dnevnika o tijeku djelovanja. Zapovjednik ŽOC-a i MRCC-a po završetku djelovanja na temelju podataka iz dnevnika o tijeku djelovanja izrađuju konačno izvješće uz obračun troškova te ga zajedno s dnevnikom o tijeku djelovanja podnose zapovjedniku Stožera.

92 Stožer je odgovoran za prekograničnu pripravnost, odgovor na iznenadni događaj, te za provedbu Subregionalnog plana. Ako Stožer smatra da neka opasnost vezana za odobalne radove može imati znatne učinke na okoliš i prirodu u drugoj državi, dužan je prije početka radova proslijediti informacije državi koja može biti pogođena i nastoji, zajedno s tom državom, usvojiti mjere kojima će se spriječiti šteta. Na zahtjev države koja smatra da bi mogla biti pogođena odobalnim radovima na području Republike Hrvatske proslijedit će im se sve tražene informacije (čl. 32. Zakona).

93 Za uklanjanje onečišćenja prouzročenog izvanrednim prirodnim događajem u moru primjenjuje se postupak kao kod izlijevanja ulja i/ili smjese ulja. 
nije moguće, korištenjem plovnih objekata. Zapovjednik Stožera ili zapovjednik ŽOC-a dužan je provesti mjere odnosno zatražiti provođenje mjera od drugih nadležnih tijela radi osiguranja onečišćenog područja od neovlaštenog pristupa i djelovanja, osiguranja nesmetanog uzorkovanja morske vode koja nije tretirana disperzantima, ${ }^{94}$ zabrane izlova ribe u onečišćenom području te zabrane plovidbe onečišćenim područjem. Disperzanti se mogu upotrijebiti ako se onečišćenje uljem i/ili smjesom ulja ne može ukloniti mehaničkim putem. ${ }^{95}$

Prije nego se pristupi čišćenju onečišćene morske obale, moraju se poduzeti pripremne aktivnosti poput uklanjanja izvora onečišćenja, sprečavanja daljnjeg širenja onečišćenja mora, osiguravanja maksimalne zaštite svih sudionika u uklanjanju onečišćenja, pripremanja područja na obali za intervenciju, formiranja interventnih timova i organiziranja poslova čišćenja obale... ${ }^{96}$ Metode čišćenja određuju se ovisno o tipu morske obale (kamenita, šljunkovita i pješčana).

Ako je počinitelj onečišćenja opasnim i štetnim tvarima poznat, istovremeno s radnjama za postupanje kod izlijevanja ulja/smjese ulja, pristupa se i utvrđivanju drugih tvari koje su ispuštene ili postoji opasnost od njihova ispuštanja. Od zapovjednika pomorskog objekta, brodovlasnika i vlasnika tereta žurno će se zatražiti dostavljanje točnih podataka o vrsti tereta kao i o njihovu smještaju na pomorskom objektu. Ovisno o poziciji pomorskog objekta, vrsti tereta i opasnosti koju teret predstavlja po zdravlje ljudi te ovisno o meteorološkim uvjetima, zapovjednik Stožera naređuje poduzimanje svih potrebnih mjera za zaštitu odnosno po potrebi evakuaciju stanovništva u blizini. ${ }^{97}$

Plan intervencija predviđa obvezu zapovjednika Stožera ili zapovjednika ŽOC-a, odnosno osobe koju zapovjednik zaduži, na informiranje javnosti o pojavi onečišćenja mora, kao i o poduzetim radnjama čišćenja i sprečavanja daljnjeg onečišćenja mora. Informiranje javnosti o onečišćenju obavlja se dnevno na osnovi konferencija za novinare i izjava za medije putem javnih glasila i ostalih medija.

94 Disperzanti su kemijska sredstva za raspršivanje i/ili uklanjanje uljnih onečišćenja s površine mora, a imaju valjanu dozvolu za uporabu.

95 Upotreba disperzanata nije dozvoljena u:

- zaštićenim područjima prirode čiji se popis nalazi u Prilogu V. točki 1. Plana intervencija,

- u zonama uzgajališta marikulture navedenima u Prilogu VI. Plana intervencija,

- zonama mriješćenja,

- područjima gdje je moguć povrat morske vode u vodotoke prilikom utjecaja morskih mijena, vjetrova ili sniženih vodostaja u vodotocima.

96 Potrebno je, također, osigurati prijevozna sredstva za osoblje, tehniku i odvoz skupljenog opasnog otpada, po potrebi osigurati smještaj i prehranu za angažirano osoblje, odrediti privremeno i konačno mjesta za odlaganje skupljenog opasnog otpada. Metode čišćenja određuju se ovisno o tipu morske obale koja može biti kamenita, šljunkovita i pješčana.

97 U nedostatku uputa za postupanje s odgovarajućim opasnim i štetnim tvarima, koristi se sustav REMPEC-a „Mediteranski integrirani informacijski sustav za potporu donošenju odluka - MIDSIS TROCS“, verzija 2.0 ili novija. 


\section{ODGOVORNOST OVLAŠTENIKA DOZVOLE}

Zakon predviđa prekršajnu odgovornost ovlaštenika dozvole za nepoštovanje odredbi ovog Zakona za što je propisana novčana kazna u iznosu od 100.000,00 kn do 1.000.000,00 kn. ${ }^{98}$ Pored novčane kazne, za određene prekršaje sankcija može biti i oduzimanje izdane dozvole. U članku 38. taksativno se navodi deset slučajeva u kojima će Koordinacija biti dužna, putem Ministarstva gospodarstva, pokrenuti postupak oduzimanja izdanih dozvola. ${ }^{99}$

Osim odredbe koja propisuje financijsku odgovornost ovlaštenika dozvole za nastalu štetu, Zakonom nisu regulirani ni visina ni temelj odgovornosti za tjelesne i materijalne štete te štete na okolišu koje bi mogle biti posljedica eventualne nesreće na odobalnom objektu, ali se u čl. 3. navodi da će se na pitanja naknade štete primjenjivati odredbe Zakona o istraživanju i eksploataciji ugljikovodika i Zakona o rudarstvu.

Nijedan od spomenutih zakonskih propisa eksplicitno ne regulira pitanje odgovornosti za štetu već ističu da će se na pitanja koja nisu njima uređena, na odgovarajući način primjenjivati ostali propisi Republike Hrvatske koja ih uređuju. Temeljem navedenoga, do primjene dolaze odredbe članaka 177. i 178. Zakona o zaštiti okoliša koje normiraju odgovornost za štetu u okolišu te Zakona o obveznim odnosima ${ }^{100}$ za tjelesne i materijalne štete.

Onečišćenje prouzročeno djelatnostima na morskom dnu i podzemlju vezano je ponajprije uz istraživanje i iskorištavanje nafte i plina. Ono, kao i onečišćenje s brodova, može biti vezano uz uobičajeni pogon platformi i drugih naprava ili može biti posljedica nezgode. Tijekom uobičajenog funkcioniranja platformi i drugih naprava, u morski okoliš može biti ispušten mulj koji se upotrebljava pri bušenju, pomiješan $\mathrm{s}$ naftom i različitim kemikalijama, voda pomiješana s naftom iz spremnika za pohranjivanje nafte, smeće i ostali otpaci. Onečišćenje koje je posljedica nezgode može proizaći iz erupcije iz bušotine, sudara broda i platforme ili druge naprave, potonuća naprave, oštećenja naftovoda.

Zakon o zaštiti okoliša kanalizira odgovornost za štetu u okolišu i/ili prijeteću opasnost od štete prema operateru i razlikuje vrste odgovornosti temeljem kojih

98 Za iste će se prekršaje kazniti i odgovorna osoba ovlaštenika dozvole novčanom kaznom u iznosu od 10.000,00 kn do 50.000,00 kn (čl. 37. Zakona).

99 To će npr. biti slučajevi: ako ovlaštenik dozvole nije poduzeo prikladne mjere sukladno ovom Zakonu, u slučaju kada odobalni radovi predstavljaju neposrednu opasnost za zdravlje ljudi ili znatno povećavaju rizik od iznenadnog događaja, velike opasnosti ili velike nesreće; ako ovlaštenik dozvole nije postupao u skladu s mjerama koje su utvrđene u izvješću o velikim opasnostima; ako ovlaštenik dozvole nije osigurao provođenje Plana intervencija odobalnog objekta; ako ovlaštenik dozvole nije osigurao da se bez odgađanja i na način propisan ovim Zakonom obavijeste Koordinacija i MRCC o iznenadnom događaju, velikoj opasnosti ili velikoj nesreći; ako ovlaštenik dozvole nije osigurao da se u slučaju iznenadnog događaja, velike opasnosti ili velike nesreće poduzmu sve mjere propisane ovim Zakonom...

100 N. N., br. 35/05, 41/08, 125/11, 78/15 ( u nastavku rada ZOO). 
će odgovarati ovisno o tome je li šteta prouzročena opasnom djelatnošću ${ }^{101}$ koju operater obavlja ili ne. Operater koji obavlja opasnu djelatnost odgovara na temelju objektivne odgovornosti, dok će za štetu u okolišu i/ili prijeteću opasnost od štete koja je posljedica djelatnosti koja se ne smatra opasnom odgovarati po načelu dokazane krivnje ili nemarnog djelovanja. ${ }^{102}$ Kako se istraživanje i eksploatacija ugljikovodika u podmorju smatra opasnom djelatnošću, ${ }^{103}$ može se zaključiti da će ovlaštenik dozvole za štetu u okolišu odgovarati na temelju objektivne odgovornosti. Sukladno rješenjima iz Zakona o zaštiti okoliša, on će biti dužan podmiriti sve troškove u vezi s poduzimanjem mjera za uklanjanje prijeteće opasnosti od štete, odnosno saniranje štete u okolišu (čl. 199. Zakona o zaštiti okoliša). ${ }^{104}$ Ako se šteta u okolišu ne može sanirati odgovarajućim mjerama, operater koji je prouzročio štetu odgovoran je za naknadu u visini vrijednosti uništenog dobra. ${ }^{105}$ Tužbu za naknadu troškova otklanjanja štete u okolišu i

101 Čl. 173. Zakona o zaštiti okoliša definira opasnu djelatnost kao djelatnost koja predstavlja rizik za okoliš i za ljudsko zdravlje. Opasne djelatnosti smatraju se opasnima zbog načina na koji se njima upravlja, proizvodi, ili zbog tvari ili sredstava koja se u njima koriste.

102 Vidi opširnije: Axel Luttenberger, „Izazovi zaštite morskog okoliša sudskim putem“, Zbornik In memoriam prof. dr. sc. Vjekoslav Šmid, Pravni fakultet Sveučilišta u Splitu. 1 (2014.), str. 133.

103 Naime, u čl. 1., t.d) Protokola o zaštiti Sredozemnog mora od onečišćenja uslijed istraživanja i iskorištavanja epikontinentalnog pojasa i morskog dna i podzemlja Barcelonske konvencije (engl. Off-shore Protocol, 1994), navode se djelatnosti u epikontinentalnom pojasu koje predstavljaju opasnu djelatnost za okoliš i ljude. To su: djelatnosti znanstvenog istraživanja vezane za bogatstva morskog dna i podzemlja, djelatnosti vezane za istraživanje (seizmološke djelatnosti, geodetska mjerenja morskog dna i podzemlja, uzimanje uzoraka, bušenje u svrhe istraživanja) i djelatnosti vezane za iskorištavanje (postavljanje uređaja u svrhu pronalaženja bogatstava, bušenje, obrada i skladištenje, transportiranje na obalu cjevovodima te teretnim brodovima, održavanje, popravci i drugi radovi). Vrlo je široko data i definicija pojma otpad, pod kojim valja razumijevati sve tvari i materijale bilo koje vrste, oblika i opisa koje nastaju uslijed izvođenja djelatnosti naznačenih u Protokolu, a koje se ili odlažu ili se namjeravaju odlagati ili moraju odlagati. Protokol nije stupio na snagu, a RH ga je potpisala. Također, i Uredba o načinu utvrđivanja šteta na okolišu (N. N., br. 139/08) u svom čl. 2. definira opasne djelatnosti kao djelatnosti opasne za okoliš i/ili život i zdravlje ljudi koje služe obavljanju neke gospodarske aktivnosti, neovisno o njihovom privatnom ili javnom, odnosno profitnom ili neprofitnom obilježju, a koje predstavljaju rizik za okoliš i/ ili za život i zdravlje ljudi. U svom prilogu 1 navodi popis opasnih djelatnosti među koje, između ostalih, ubraja i gospodarenje otpadom iz istraživanja i eksploatacije mineralnih sirovina (ugljikovodika).

104 Sukladno postavljenom zahtjevu za naknadu troškova i sanacije štete obvezan je nadoknaditi:

- troškove procjene štete,

- troškove utvrđivanja mjera za sanaciju okoliša u postupku izrade i odobravanja sanacijskog programa,

- troškove povrata okoliša u stanje prije nastanka štete ako je takav povrat moguć, odnosno troškove sanacije posljedica štete u okolišu, troškove kompenzacijskih mjera,

- troškove provedbe mjera otklanjanja prijeteće opasnosti od šteta,

- troškove provedbe mjera za sprečavanje ili ublažavanje štete u okolišu,

- troškove nadzora provedbe mjera,

- sve druge nepredviđene troškove nastale uslijed provedbe mjera otklanjanja štete.

105 Vrijednost naknade treba biti približna ekonomskoj i ekološkoj vrijednosti uništenog dobra. 
troškova u svezi s otklanjanjem prijeteće opasnosti od štete nadležnom sudu, ${ }^{106}$ sukladno ovom Zakonu, podnosi Republika Hrvatska. ${ }^{107}$

Odgovornost za tjelesne i materijalne štete nastale od opasne djelatnosti pravno je regulirana čl. 1045, st. 3. ZOO-a u kojem stoji da se za štetu od stvari ili djelatnosti od kojih potječe povećana opasnost štete za okolinu odgovara bez obzira na krivnju, dakle, na temelju objektivne odgovornosti kao i za štetu u okolišu. ZOO u čl. 1046. štetu definira kao umanjenje nečije imovine (obična šteta), sprečavanje njezina povećanja (izmakla korist) i povredu prava osobnosti (neimovinska šteta). Neimovinsku štetu čini već sama povreda prava osobnosti, a pretrpljeni fizički ili psihički bolovi ili strah, izazvani štetnom radnjom, samo su mjerilo težine povrede prava osobnosti i uzimaju se u obzir prilikom utvrđivanja visine naknade štete. ${ }^{108}$

\section{ZAKLJUČAK}

Imajući u vidu da je energetska stabilnost i samodostatnost bitan preduvjet gospodarskog napretka svake zemlje, Republika Hrvatska se odlučila na dodatna ulaganja u energetski sektor. Tako je posljednjih godina zapažen razvoj solarne energije u Hrvatskoj te se priprema i realizacija prihvatnog terminala za ukapljeni prirodni plin. Posljednji korak, napravljen u tom smijeru, jest reaktiviranje istraživanja i eksploatacije ugljikovodika u Jadranu.

Prednosti nafte i plina, kao neobnovljivih energenata, odavno su poznate baš kao i činjenica da im Jadran obiluje. Tako su se na Jadranu prve bušotine pojavile još davne 1961. godine da bi do 2004. godine bila izrađena 51 bušotina. Međutim, kako bi se zaštitili nacionalni interesi u ovom području te kako bi se stvorili nužni preduvjeti za nova ulaganja u odobalno istraživanje i eksploataciju ugljikovodika, trebalo je formirati odgovarajući pravni okvir. Pored postojećih relevantnih propisa koji se odnose na ovu sferu gospodarstva te zakonskih i podzakonskih propisa iz područja zaštite okoliša, donošenje Zakona o sigurnosti pri odobalnom istraživanju i eksploataciji ugljikovodika u srpnju 2015. godine bilo je presudno za stvaranje sustavne i cjelovite legislative ovog kompleksnog multidisciplinarnog

106 ZZO ne sadrži ni posebne odredbe o nadležnosti sudova pa dolaze do primjene opća pravila parničnoga postupka po kojima postoji se tužna na naknadu štete može podnijeti pred nekoliko različitih sudova. Osim suda koji je nadležan prema prebivalištu odnosno boravištu tuženog, nadležan može biti i sud na čijem području je štetna radnja učinjena kao i sud na čijem je području šteta nastupila.

107 Na naknadu štete će, kao oštećenik, biti ovlaštena osoba koja trpi ili je pretrpjela štetu zbog onečišćavanja okoliša. Kad je šteta nastala na nekretninama koje se smatraju općim dobrima kao što su atmosferski zrak, voda u rijekama, jezerima i morima, morska obala i dr., tužbu radi naknade štete ovlašten je u ime Republike Hrvatske podnijeti nadležni državni odvjetnik. ZZO ne sadrži posebne odredbe o zastari prava na podnošenje zahtjeva za naknadu štete pa se na navedeno pitanje primjenjuju odredbe ZOO-a o zastari zahtjeva za naknadu štete. Zahtjev za naknadu štete zastarijeva u subjektivnom roku od tri godine, odnosno u objektivnom roku od pet godina (čl. 230. ZOO).

108 ZOO u svom čl. 19. Pod pravima osobnosti fizičke osobe razumijeva pravo na život, tjelesno i duševno zdravlje, ugled, čast, dostojanstvo, ime, privatnost osobnog i obiteljskog života, slobodu i dr. Pravna osoba ima sva navedena prava osobnosti, osim onih vezanih uz biološku bit fizičke osobe, a osobito pravo na ugled i dobar glas, čast, ime, odnosno tvrtku, poslovnu tajnu, slobodu privređivanja ... 
pitanja. Treba naglasiti da se donošenjem ovog propisa, ujedno, postigla i daljnja harmonizacija našeg zakonodavstva s pravom Europske unije.

Odredbe Zakona primjenjivat će se na odobalne objekte koji se nalaze ili plove u unutarnjim morskim vodama i u teritorijalnom moru Republike Hrvatske, te u epikontinentalnom pojasu Republike Hrvatske koji obuhvaća morsko dno i morsko podzemlje izvan vanjske granice teritorijalnog mora Republike Hrvatske u smjeru pučine do granice epikontinentalnog pojasa sa susjednim državama na kojima Republika Hrvatska, u skladu s međunarodnim pravom, ostvaruje jurisdikciju i suverena prava. Cilj koji se želi postići donošenjem ovoga Zakona jest stvaranje odgovarajuće pravne regulative koja bi trebala pridonijeti sprečavanju velikih nesreća tijekom odobalnog istraživanja i eksploatacije ugljikovodika, ali, ujedno, i uređivanje načina primjene propisa, sprečavanja i postupanja u slučaju kada se dogode velike nesreće koje su povezane s izvođenjem odobalnih radova.

Zakon ističe dvije osobe koje imaju ključna prava i obveze sukladno njegovim odredbama. To su ovlaštenik dozvole i Koordinacija za sigurnost pri odobalnom istraživanju i eksploataciji ugljikovodika. Ovlaštenik dozvole jest pravna osoba kojoj je izdana dozvola za istraživanje i eksploataciju ugljikovodika, a koja je, prema Zakonu, odgovorna za odobalne radove. U tom smislu ovlaštenik je, isključivo, financijski odgovoran za sprečavanje i sanaciju štete u okolišu i prirodi prouzročenu odobalnim radovima. Slijedom navedenoga, dužan je, za vrijeme trajanja izdane dozvole, imati i održavati na snazi odgovarajuće police osiguranja. Koordinacija za sigurnost pri odobalnom istraživanju i eksploataciji ugljikovodika, s druge strane, nadležno je tijelo imenovano u skladu s ovim Zakonom, a koje je nadležno za provedbu djelatnosti koje su nadležnom tijelu dodijeljene ovim Zakonom. Sačinjavaju je predstavnici raznih državnih tijela i institucija. Sporno je, međutim, što jedan od predstavnika Koordinacije dolazi iz redova Agencije za ugljikovodike iz razloga što je, upravo, navedena Agencija tijelo nadležno za promicanje korištenja naftnih i plinskih resursa i kao takvo prilično pristrano te, samim tim, neadekvatno da bude uključeno u nadzor sigurnosti i zaštite okoliša pri istraživanju i eksploataciji ugljikovodika u našem podmorju. Istim se dovodi u pitanje i poštovanje propisanog zahtjeva za neovisnošću i objektivnosću Koordinacije.

Zakon propisuje i obvezu izrade Plana intervencija odobalnog objekta koji mora biti dosljedan Planu intervencija kod iznenadnih onečišćenja mora. Plan intervencija kod iznenadnih onečišćenja mora jest dokument održivog razvitka i zaštite okoliša kojim se utvrđuju postupci i mjere za predviđanje, sprečavanje, ograničavanje, spremnost za i reagiranje na iznenadna onečišćenja mora i na izvanredne prirodne događaje u moru radi zaštite morskog okoliša, a koji je usklađen s međunarodnim ugovorima iz područja zaštite morskog okoliša čija je stranka Republika Hrvatska. U njemu se taksativno navodi što će se smatrati rizikom, odnosno prijetnjom od onečišćenja okoliša; definiraju se subjekti za provedbu Plana intervencija te postupci i mjere reagiranja za smanjenje šteta u morskom okolišu. Prema odredbama ovog Zakona, Plan intervencija kod iznenadnih onečišćenja 
mora donosi Vlada Republike Hrvatske, na prijedlog ministarstva nadležnog za zaštitu okoliša i prirode uz prethodno mišljenje Koordinacije. Navedena odredba nije usuglašena s odredbom Zakona o zaštiti okoliša iz čl. 57. koji određuje da će Plan i njegove izmjene i dopune izraditi Ministarstvo u suradnji sa središnjim tijelima državne uprave nadležnima za poslove: pomorstva, unutarnjih poslova, vodnoga gospodarstva, vanjskih poslova, financija, obrane, ribarstva te zaštite i spašavanja, a donijet će ga Vlada. Spomenutu neusklađenost trebalo bi što skorije otkloniti.

Zakon predviđa prekršajnu odgovornost ovlaštenika dozvole za nepoštovanje odredbi ovog Zakona, ali ne i građanskopravnu odgovornost za tjelesne i materijalne štete te štete na okolišu koje bi mogle biti posljedica eventualne nesreće na odobalnom objektu. U pogledu navedenih pitanja upućuje na odgovarajuće hrvatske propise. Temeljem toga, do primjene dolaze odredbe Zakona o zaštiti okoliša i Zakona o obveznim odnosima. Sukladno Zakonu o zaštiti okoliša, ovlaštenik dozvole isključivo je odgovoran za štetu u okolišu i to na temelju objektivne odgovornosti. On će biti dužan podmiriti sve troškove u vezi s poduzimanjem mjera za uklanjanje prijeteće opasnosti od štete, odnosno saniranje štete u okolišu. S druge strane, odgovornost za tjelesne i materijalne štete nastale od opasne djelatnosti pravno je regulirana Zakonom o obveznim odnosima koji, također, propisuje objektivnu odgovornost odgovorne osobe.

Za zaključiti je da postojeći pravni okvir sigurnosti i zaštite okoliša pri odobalnom istraživanju i eksploataciji ugljikovodika predstavlja primjer sustavne i cjelovite regulative odnosnog područja. Međutim, ne treba, nikako, zanemariti tehnički aspekt cijele problematike koji je, zasigurno, jednako važan ako ne i važniji. Naime, odgovarajuća pravna regulativa je neophodna, ali nije i dostatna za postizanje željenih ciljeva sigurnosti djelatnosti u podmorju i zaštite Jadrana. Dakle, prilikom realizacije novih bušotina u hrvatskom Jadranu treba osobitu pozornost posvetiti upravo tehničkim zahtjevima jer ukoliko dođe do propusta u tom dijelu, ni adekvatna pravna regulativa neće anulirati nastalu štetu.

\section{Literatura:}

Amižić Jelovčić, P.: „Onečišćenje morskog okoliša balastnim vodama s posebnim osvrtom na međunarodnu konvenciju o nadzoru i upravljanju brodskim balastnim vodama i talozima iz 2004. godine“, Zbornik Pravnog fakulteta u Splitu, br. 4, Split, 2008.

Amižić Jelovčić, P. - Primorac, Ž. - Mandić, N.: „Pravni aspekt organizacije i djelokruga rada Obalne straže u Republici Hrvatskoj s posebnim osvrtom na Zakon o Obalnoj straži“, Poredbeno pomorsko pravo - Izazovi i perspektive u pomorskom pravu $i$ pravu mora: Interesi $R H$, br. 164, Zagreb, 2010.

Amižić Jelovčić, P. - Primorac, Ž. - Mandić, N.: „Obalna straža i zaštita prava i interesa Republike Hrvatske na moru“, Zbornik radova sa znanstveno-stručnog skupa In memoriam prof. dr. sc. Vjekoslav Šmid, Split, 2012.

Bolanča, D., - Naprta, R.: More naše plavo - Sigurnost plovidbe, zbirka propisa, Zagreb-Split, 2009. 
Brnabić, R. - Ivkošić,M.: „Ugovor o izvođenju radova bušenja u svezi s vađenjem nafte na moru (offshore drilling)“, Zbornik radova „In memoriam prof. Dr. sc. Vjekoslav Šmid“, Rab, 2014.

Ćorić, D.: Međunarodni sustav odgovornosti i naknade štete zbog onečišćenja mora uljem, Zagreb, 2002.

Ćorić, D.: Onečišćenje mora s brodova-međunarodna i nacionalna pravna regulativa, Rijeka 2009. $p d f$

Kavedžija, B.: Tehnika izrade bušotina, www.rgn.hr/-bkave/Materijali/1UVOD Idio.

Lončarić Horvat, O. i dr., Osnove prava okoliša, Zagreb, 1997.

Luttenberger, A.: „Izazovi zaštite morskog okoliša sudskim putem“, Zbornik In memoriam prof. dr. sc. Vjekoslav Šmid, Pravni fakultet Sveučilišta u Splitu. 1 (2014.)

Rudolf, D.: Enciklopedijski rječnik međunarodnog prava mora, Zagreb, 2012.

Skorupan Wolff, V. - Petrinović, R.: „Međunarodna konvencija o uklanjanju podrtina“, Poredbeno pomorsko pravo, br. 162, Zagreb, 2008.

Stanković, G., „OPRC Konvencija - novo područje IMO-ove aktivnosti u borbi protiv zagađenja naftom“, Uporedno pomorsko pravo, br. 127-128, Zagreb, 1990. $78 / 15$

Zakon o sigurnosti pri odobalnom istraživanju i eksploataciji ugljikovodika, N. N., br.

Zakon o rudarstvu, N. N., br. 56/13 i 14/14

Zakon o istraživanju i eksploataciji ugljikovodika, N. N., br. 94/13, 14/14

Zakon o zaštiti okoliša, N. N., br. 80/13, 153/13, 78/15

Zakon o osnivanju Agencije za ugljikovodike, N. N., br. 14/14

Pomorski zakonik, N. N., br. 181/04, 76/07, 146/08, 61/11, 56/13, 26/15

Zakon o obveznim odnosima, N. N., br. 35/05, 41/08, 125/11, 78/

Pravilnik o bitnim tehničkim zahtjevima, sigurnosti i zaštiti pri istraživanju i eksploataciji ugljikovodika iz podmorja Republike Hrvatske, N. N., br. 52/10

Pravilnik o suradnji Obalne straže s tijelima nadležnima za nadzor kod iznenadnog onečišćenja mora, N. N., br. 153/09

Plan intervencija kod iznenadnih onečišćenja mora, N. N., br. 92/08

Sporazum o Subregionalnom planu intervencija za sprečavanje, spremnost za i reagiranje na iznenadna onečišćenja Jadranskog mora većih razmjera, N. N. - M. U., br. $7 / 08$

Uredba o opasnim tvarima u vodama, N. N., br. 137/08

Direktiva 2013/30/EU Europskog parlamenta i Vijeća o sigurnosti odobalnih naftnih i plinskih djelatnosti i o izmjeni direktive 2004/35/EZ, SL L 178., 28. 6. 2013.

Direktiva 2004/35/EZ o odgovornosti za okoliš u pogledu sprečavanja i otklanjanja štete u okolišu SL L 143/56, 21. 4. 2004.

Provedbena uredba Komisije (EU) br. 1112/2014 o utvrđivanju zajedničkog obrasca pomoću kojeg operateri i vlasnici odobalnih naftnih i plinskih objekata razmjenjuju informacije o pokazateljima velikih opasnosti te zajedničkog obrasca pomoću kojeg 
države članice objavljuju informacije o pokazateljima velikih opasnosti, SL L 302., 22. 10. 2014.

Međunarodna konvencija o pripravnosti, akciji i suradnji za slučaj onečišćenja uljem, N. N. - M. U., br. 2/97

Konvencija o pristupu informacijama, sudjelovanju javnosti u odlučivanju i pristupu pravosuđu u pitanjima okoliša, N. N. - M. U., br. 01/07

www.mingo.hr

www.vlada.gov.hr

\section{CRAOTIAN LEGAL FRAMEWORK FOR SAFETY OF AND PROTECTION OF MARINE ENVIRONMENT IN OFFSHORE EXPLORATION EXPLOITATION OF HYDROCARBONS}

In order to reduce the import of energy sources and to improve energy situation in the Republic of Croatia, our country has decided to revive offshore exploration and exploitation of hydrocarbons. The prerequisite was the creation of an appropriate legal framework, which was achieved by the adoption of the Act on safety in offshore exploration and exploitation of hydrocarbons in July 2015. The author of this paper reviews the provisions of the before mentioned Act with special emphasis on the protection of marine environment. Consequently, the author also analyzes the provisions of the Plan of Intervention in the Case of Accidental Marine Pollution in correlation with the aforementioned Law.

Key words: legislation, offshore exploration, offshore exploitation, hydrocarbons, protection of marine environment, liability for damage 